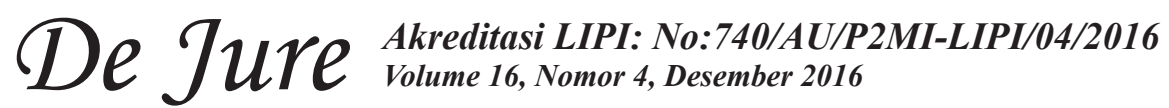

Jurnal Penelitian Hukum De Jure adalah majalah hukum triwulan (Maret, Juni, September dan Desember) diterbitkan oleh Badan Penelitian dan Pengembangan Hukum dan HAM Kementerian Hukum dan HAM RI bekerjasama dengan IKATAN PENELITI HUKUM INDONESIA (IPHI) Pengesahan Badan Hukum Perkumpulan Keputusan Menteri Hukum dan Hak Asasi Manusia Nomor : AHU-13.AHA.01.07 Tahun 2013, Tanggal 28 Januari 2013, bertujuan sebagai wadah dan media komunikasi, serta sarana untuk mempublikasikan aneka permasalahan hukum yang aktual dan terkini bagi para peneliti hukum Indonesia khususnya dan kalangan masyarakat pemerhati hukum pada umumnya.

Penanggung Jawab

Y. Ambeg Paramarta, S.H.,M.Si

(Kepala Badan Penelitian dan Pengembangan Hukum dan Hak Asasi Manusia)

\section{Pemimpin Umum}

Marulak Pardede, S.H.,M.H.,APU

(Ketua Ikatan Peneliti Hukum Indonesia)

\section{Wakil Pemimpin Umum}

T. Daniel L. Tobing, S.H

(Kepala Pusat Pengembangan Data dan Informasi Peneliti Hukum dan Hak Asasi Manusia)

DR. Agus Anwar, S.H.,M.H

(Kepala Pusat Penelitian dan Pengembangan Hukum)

Pemimpin Redaksi

Akhyar Ari Gayo, S.H.,M.H.,APU (Hukum Islam, BALITBANGKUMHAM)

\section{Anggota DewanRedaksi}

DR. Ahmad Ubbe, S.H.,M.H., APU (Hukum Adat, BALITBANGKUMHAM)

Mosgan Situmorang, S.H.,M.H (Hukum Perdata, BALITBANGKUMHAM)

Syprianus Aristieus, S.H.,M.H (Hukum Perusahaan, BALITBANGKUMHAM)

Nevey Varida Ariani, S.H.,M.H (Hukum Pidana, BALITBANGKUMHAM)

Eko Noer Kristiyanto, S.H (Hukum Perdata, BALITBANGKUMHAM)

Muhaimin, S.H (Hukum Islam, BALITBANGKUMHAM)

\section{Redaksi Pelaksana}

Yatun, S.Sos

Sekretaris

M. Virsyah Jayadilaga, S.Si.,M.P

Asmadi

\section{Tata Usaha}

Dra. Evi Djuniarti, M.H

Galuh Hadiningrum, S.H

Suwartono 


\section{TUTe $\begin{aligned} & \text { Akreditasi LIPI: No:740/AU/P2MI-LIPI/04/2016 } \\ & \text { Volume 16, Nomor 4, Desember } 2016\end{aligned}$}

Teknologi Informasi dan Desain Layout

Risma Sari, S.Kom., M.Si (Teknologi Informasi)

Machyudhie, S.T (Teknologi Infornasi)

Saefullah, S.ST.,M.Si (Teknplogi Informasi)

Agus Priyatna, S.Kom (Desain Layout)

Teddy Suryotejo

\section{Mitra Bestari}

Prof. DR. Rianto Adi, M.A (Sosilogi Hukum, UNIKA ATMAJAYA JAKARTA)

Prof. DR. Jeane Neltje Saly, S.H.,M.H (Hukum Humaniter, UNIV. 17 Agustus 1945 Jakarta)

Prof. DR. Hibnu Nugroho, S.H (Hukum Fidana, FH. UNSOED)

DR. Farhana, S.H.,M.H (Hukum Pidana, Fak. Hukum Universitas Islam Jakarta)

DR. Ridwan Nurdin, M.A (Hukum Syariah, Fakultas Syariah Univ. Arraniri Banda Aceh)

DR. Hadi Supratikta (Administrasi Pemerintahan, Balitbang Kemendagri)

\section{Alamat Redaksi:}

Gedung Badan Penelitian dan Pengembangan Hukum dan Hak Asasi Manusia

Kementerian Hukum dan Hak Asasi Manusia Republik Indonesia

Jl. HR. Rasuna Said Kav.4-5, Kuningan, Jakarta Selatan

Telepon, (021)2525015, Faksimili (021) 2526438

Email :

jurnaldejure@yahoo.com

balitbangkumham@gmail.com

ejournaldejure@gmail.com

\section{Percetakan}

PT Pohon Cahaya

Jalan Gedung Baru 18 Jakarta Barat 11440

Telpon (021) 5600111, Faksimili (021) 5670340

Redaksi menerima naskah karya asli yang aktual dalam bidang hukum berupa hasil penelitian dari berbagai kalangan, seperti: peneliti hukum, praktisi dan teoritisi, serta berbagai kalangan lainnya. Tulisan-tulisan yang dimuat merupakan pendapat pribadi penulisnya, bukan pendapat redaksi.

Redaksi berhak menolak, menyingkat naskah tulisan sepanjang tidak mengubah isinya. Naskah tulisan dapat dikirim ke alamat redaksi, maksimum 30 halaman A4, diketik spasi dua rangkap dikirim melalui Email: jurnaldejure@yahoo.com atau melalui aplikasi Open Journal System (OJS) pada URL/website: ejournalbalitbangham.go.id 


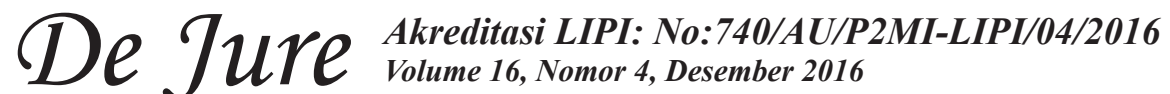

\section{DAFTAR ISI}

Halaman

\section{DAFTAR ISI}

ADVERTORIAL

Aspek Hukum Pemberian Remisi Kepada Narapidana Korupsi

(Legal Aspects of Remissions to Corruptors)

$375-394$

Mosgan Sitomorang

DAFTAR RIWAYAT HIDUP

505 - 506

PEDOMAN PENULISAN

507- 508 


\section{De TuPe $\begin{aligned} & \text { Akreditasi LIPI: No:740/AU/P2MI-LIPI/04/2016 } \\ & \text { Volume 16, Nomor 4, Desember } 2016\end{aligned}$}

Puji syukur kehadirat Allah SWT, Jurnal Penelitian Hukum De Jure yang diterbitkan Badan Penelitian dan Pengembangan Hukum dan HAM Kementerian Hukum dan Hak Asasi Manusia bekerjasama dengan Ikatan Peneliti Hukum Indonesia dapat menerbitkan Volume 16 Nomor 4, Desember 2016.

Para pembaca Jurnal Penelitian Hukum De Jure yang tercinta, sebagaimana diketahui bahwa pada tanggal 10 Desember setiap tahunnya diperingati sebagai Hari Hak Asasi Manusia sedunia. Tanggal ini dipilih untuk menghormat Majelis Umum PBB yang mengadopsi dan memproklamirkan Deklarasi Universal Hak Asasi Manusia, sebuah pernyataan global tentang hak asasi manusia pada 10 Desember 1948.

Apabila menilik Hukum dan HAM, merupakan konsepsi kemanusiaan dan relasi sosial yang dilahirkan dari sejarah peradaban manusia di seluruh penjuru dunia. Hukum dan HAM juga dapat dimaknai sebagai hasil perjuangan manusia untuk mempertahankan dan mencapai harkat kemanusiaannya. Agar HAM dapat ditegakkan dalam berbagai kehidupan harus ada instrumen yang mengaturnya. Instrumen tersebut berisi aturanaturan bagaimana HAM itu ditegakkan dan mengikat seluruh warganegara. Sebagai negara yang menjunjung tinggi HAM Indonesia telah memiliki setidak-tidaknya empat instrumen HAM, yakni UUD 1945, TAP MPR Nomor XVII/MPR/1998, UU Nomor 39 Tahun 1999 tentang Hak Asasi Manusia.

Dari beberapa intrumen yang ada tersebut berharap perlindungan dan penegakan HAM kedepanya dapat meningkat, karena masih banyak kekurangan-kekurangan yang harus diperbaiki oleh pemerintah. Seperti lebih difungsikan secara maksimal lembaga-lembaga yang memiliki tugas khusus menegakan HAM.

Dalam rangka memperingati Hari Hak Asasi Manusia Sedunia tersebut, Dewan Redaksi mengangkat tuisan-tulisan dari para peneliti di lingkungan Kementerian Hukum dan HAM yang bersinggungan dengan penegakan Hukum dan HAM di Indonesia.

Akhirnya kami menyampaikan ucapan terima kasih kepada Kepala Badan Penelitian dan Pengembangan Hukum dan HAM Kementerian Hukum dan HAM RI dan Ketua Ikatan Peneliti Hukum Indonesia dalam penerbitan buku ini. Dan juga kami ucapkan terima kasih kepada Prof. DR. Rianto Adi, M.A., Prof. DR. Jeane Neltje Saly, S.H.,M.H., Prof. DR. Hibnu Nugroho, S.H., DR. Farhana, S.H., M.H., DR. Ridwan Nurdin, M.A.,dan DR. Hadi Supratikta, Selaku Mitra Bestari yang telah bersedia membantu memeriksa dan mengoreksi tulisan dari para penulils.

Jakarta, Desember 2016 


\title{
ASPEK HUKUM PEMBERIAN REMISI KEPADA NARAPIDANA KORUPSI (Legal Aspect of Remissions To Corruptors)
}

\author{
Mosgan Situmorang \\ Peneliti pada Pusat Penelitian dan Pengembangan Hukum, Badan Penelitian \\ dan Pengembangan Hukum dan Hak Asasi Manusia \\ Kementerian Hukum dan Hak Asasi Manusia Republik Indonesia \\ Jalan HR Rasuna Said Kavling 4 -5, Jakarta Selatan 12920 \\ Telepon (021)2525015 Faksimili (021)2526438 \\ HP: 081382993780 - Email: mosgansit@yahoo.com \\ Tulisan Diterima: 2-11-2016; Direvisi: 24-11-2016; \\ Disetujui Diterbitkan: 22-12-2016
}

\begin{abstract}
Remission is one of convict rights ruled in the Law Number 12 Year 1995 concerning Correctional. It is given, at least twice a year that is in independence day of Indonesia on 17 August and in religious holidays. Basically, all convicts including criminal child have right to remission during meet certain requirements as ruled in legislation. In 2012, government issued regulation that have a tight remission to a certain convict such as corruptor. Obviously, it became pros and cons. It came up from the Minister of Law and Human Rights to revise Government Regulation Number 99/2012. Its policy made arguing from many parties especially law enforcers and anti-corruption activists. But, some legislative members (DPR) precisely, supported the Minister ' will. This research is intended to know further information of this remission. The focus of this research is about pattern of criminalization and its correlation with remission, procedure of remission, supervision and positive and negative aspects. It is a empirical normative method. It concludes that there are differences between pattern of criminalization and pattern of convict instilling, a tight remission with a letter from justice collaborator have potential to delete corruptor rights, supervision carried out improperly, positive aspect of remission to corruptor can lessen budget, while negative aspect can be abused. It suggests that Government Regulation Number 99/2012 must be revised.
\end{abstract}

Keywords: law aspect of remission

\begin{abstract}
ABSTRAK
Remisi adalah salah satu hak narapidana yang diatur dalam Undang-Undang Nomor 12 Tahun 1995 Tentang Pemasyarakatan. Remisi diberikan setidaknya dua kali dalam setahun yaitu pada peringatan hari kemerdekaan setiap tanggal 17 Agustus dan pada hari besar keagamaan. Pada dasarnya setiap warga binaan pemasyarakatan termasuk anak pidana berhak mendapat remisi asal memenuhi syarat-syarat tertetu yang diatur dalam perturan perundang-undangan. Pada tahun 2012 pemerintah mengeluarkan peraturan pemerintah yang bernuansa pengetatan pemberian remisi terhadap narapidana tertentu, dimana salah satunya adalah terhadap narapidana korupsi. Pengetatan pemberian remisi terhadap narapidana korupsi saat ini menimbulkan pro dan kontra. Hal ini muncul setelah adanya keinginan Menteri Hukum dan Ham untuk merevisi peraturan pemerintah Nomor 99/2012. Hal ini banyak ditentang terutama oleh penegak hukum dan masyarakat penggiat anti korupsi. Akan tetapi sebagian anggota DPR justru mendukung keinginan Menteri Hukum dan Ham tersebut. Untuk mengetahui lebih lanjut mengenai pemberian remisi ini maka diadakan penelitian dengan judul seperti di atas. Permasalah yang akan diteliti adalah mengenai pola pemidanaan dan hubungannya dengan pemberian remisi, prosedur pemberian remisi, pengawasan dan aspek positif daan negatif pemberian remisi. Metode yang digunakan adalah normatif empiris. Berdasarkan hasil penelitian disimpulkan bahwa terdapat perbedan pola pemidanaan dan pola pembinaan narapidana, pengetatan pemberian remisi dengan mensyaratkan adanya surat keterangan Justice Collaborator berpotensi menghilangkan hak narapidana korupsi, pengawasan belum dilaksanakan sebagaimana mestinya, aspek positif pemberian remisi terhadap narapidana korupsi dapat
\end{abstract}


mengurangi anggaran sedangkan negatifnya adalah berpotensi disalah gunakan. Berdasarkan hasil penelitian ini disarankan agar PP99/2012 di revisi.

\section{Kata kunci: Aspek Hukum Remisi}

\section{PENDAHULUAN}

Sistem pemasyarakatan merupakan rangkaian sistem pemidanaan yang bertujuan agar Warga Binaan Pemasyarakatan menyadari kesalahannya, memperbaiki diri, dan tidak mengulangi tindak pidana sehingga dapat diterima kembali dilingkungan masyarakat. Oleh karena itu, pemidanaan perlumemperhatikan sisi kemanusiaan atau perlindungan HAM. Salah satu upaya yang dilakukan adalah dengan memberikan remisi sebagaimana diatur dalam Undang-Undang Nomor 12 tahun 1995 tentang Pemasyarakatan. Sistem Pemasyarakatan menjamin hak-hak narapidana sebagaimana tercantum dalam Undang-Undang Nomor 12 Tahun 1995 tentang Pemasyarakatan antara lain: mendapat pengurangan masa pidana (remisi) sebagaimana diatur dalam Pasal 14 (1) huruf i. Remisi pada dasarnya diberikan tanpa membedakan narapidana, sebagai tanggung jawab pemerintah dalam memberikan perlindungan dan pemenuhan terhadap hak-hak narapidana. Meskipun demikian, dalam Peraturan Pemerintah Nomor 99 tahun 2012 tentang Perubahan Kedua atas Peraturan Pemerintah Nomor 32 tahun 1999 tentang Syarat dan Tata Cara Pelaksanaan Hak Warga Binaan Pemasyarakatan, terdapat perbedaan "persyaratan" bagi narapidana korupsi, terorisme, narkotika, serta psikotropika. Perbedaan tersebut dengan pertimbangan bahwa "kriteria" tindak pidana tersebut di atas memiliki dampak lebih besar dibandingkan tindak pidana yang lain.

Pelaku tindak pidana korupsi memiliki kekuasaan, modal(politik), danposisi strategisyang memungkinkan atau mempengaruhi pengambilan kebijakan publik. Dengan pertimbangan ini, perlakuan terhadap pelaku tindak pidana korupsi dipandang perlu untuk tidak dipersamakan dengan pelaku tindak pidana umum. Banyak koruptor yang telah divonis bersalah oleh pengadilan dengan pidana perampasan kemerdekaan badan selama sekian tahun, tetapi dapat dengan sangat cepat "menyelesaikan" masa pidananya di Lembaga Pemasyarakatan. Salah satu hal yang menyebabkannya adalah pemberian remisi kepada koruptor tersebut.

Berdasarkan PP Nomor 28 Tahun 2006 tentang Perubahan Atas PP Nomor 32 Tahun 1999 tentang Syarat dan Tata Cara Pelaksanaan Hak Warga Binaan Pemasyarakatan, "Bagi Narapidana yang dipidana karena melakukan tindak pidana terorisme, narkotika dan psikotropika, korupsi, kejahatan terhadap keamanan negara dan kejahatan hak asasi manusia yang berat, dan kejahatan transnasional terorganisasi lainnya, dapat diberikan remisi apabila memenuhi persyaratan sebagai berikut: berkelakuan baik, dan telah menjalani $1 / 3$ (satu per tiga) masa pidana". Hal ini tercanyum dalam Pasal 34 ayat (3) PP Nomor 28 Tahun 2006 tentang Perubahan Atas PP Nomor 32 Tahun 1999 tentang Syarat dan Tata Cara Pelaksanaan Hak Warga Binaan Pemasyarakatan.

Ekspektasi masyarakat tentang penjeraan bagi pelaku korupsi terus menguat. Bahwa pemberian remisi bagi narapidana korupsi, meskipun telah diberlakuan secara berbeda berdasarkan PP Nomor 28 Tahun 2006 tentang Perubahan Atas PP Nomor 32 Tahun 1999 tentang Syarat dan Tata Cara Pelaksanaan Hak Warga Binaan Pemasyarakatan, dianggap belum mampu menjadi penggentar bagi pejabat-pejabat pemangku kekuasaan untuk tidak melakukan korupsi.

Dalam PP Nomor 99 tahun 2012 tentang Perubahan Kedua Atas PP Nomor 32 Tahun 1999 tentang Syarat dan Tata Cara Pelaksanaan Hak Warga Binaan Pemasyarakatan, persyaratan tersebut diubah Dengan cara menambah syarat adanya Surat keterangan yang menerngkan bahwa bahwa narapidana tersebut adalah seorang Justice Collaborator sebagaimana dinyatakan dalam Pasal 34. Sebagai tindak lanjutnya Menteri Hukum dan Hak Asasi Manusia telah menerbitkan SuratEdaran Menkumham Nomor M.HH-04.PK.01.05.06 Tahun 2013 tentang Petunjuk Pelaksanaan Pemberlakuan PP Nomor 99 tahun 2012 tentang Perubahan Kedua Atas PP Nomor 32 Tahun 1999 tentang Syarat dan Tata Cara Pelaksanaan Hak Warga Binaan Pemasyarakatan. Surat Edaran ini dikeluarkan pada tanggal 12 Juli 2013.

Di sisi lain Menteri Hukum dan HAM saat ini beberapa waktu yang lalu mengatakan, akan memberikan remisi kepada terpidana koruptor lewat revisi PP Nomor 99 tahun 2012 tentang Perubahan Kedua Atas PP Nomor 32 Tahun 1999 tentang Syarat dan Tata Cara Pelaksanaan 
Hak Warga Binaan Pemasyarakatan, dengan alasan penegakan hukum di abad modern sudah meninggalkan hukuman kepada narapidana dengan tujuan pembalasan. Sebab saat itu pemidanaan memiliki tujuan mencegah pidana demi pengayoman masyarakat, menerapkan rasa damai, tidak ada maksud membuat efek jera. "Paradigma pemidanaan pembalasan itu bentuk yang paling klasik yang sudah ditinggalkan semenjak abad 17. Penjeraan juga sudah selesai dua abad lalu. Yang sekarang diterapkan itu reintegrasi sosial, karena masalah pidana bukan masalah pribadi, tapi persoalan lingkungan." (http://sp.beritasatu.com/home/menkumhambuka-kemungkinan-revisi-pp-no-99-tahun2012-tentang -pemberian-remisi/91833,di akses pada tanggal 9 Februari 2016). Kongres PBB tahun 1984 di Venezuela membahas tentang pencegahan dilakukannya kejahatan, antara lain menyatakan bahwa narapidana yang dijatuhi hukuman penjara seumur hidup adalah tidak sesuai dengan tujuan utama pemidanaan yaitu reintgrasi terhukum kedalam masyarakat (Marlina, 2011)

Dalam praktiknya memang masih terdapat beberapa persoalan terkait pemberian remisi antara lain: pemberian remisi terhadap warga binaan dipandang sebagai wilayah kekuasaan eksekutif sehingga tidak tepat ketika salah satu persyaratan pemberian remisi masih melibatkan instansi lain misalnya dalam syarat adanya pernyataan "Justice Collaborator" yang dikeluarkan oleh instansi penegak hukum; belum ada indikator yang jelas untuk pemberian remisi (misalnya apa saja indikator seorang napi "berkelakuan baik" dan layak mendapatkan remisi); serta terlalu banyaknya jumlah dan jenis remisi yang diberikan pada warga binaan.

Berdasarkan uraian di atas, maka perlu dilakukan penelitian berkaitan dengan pemberian remisi khususnya kepada pelaku tindak pidana korupsi (koruptor) yang berjudul "Aspek Hukum Pemberian Remisi Kepada Narapidana Korupsi". Permasalahan yang akan menjadi fokus dalam penelitian ini adalah: Bagaimana pola pemidanaan dan kaitannya dengan konsep pemberian remisi, bagaimana prosedur dan pelaksanaan pemberian remisi narapidana korupsi, bagaimana fungsi pengawasan dalam pemberian remisi narapidana korupsi?, dan apa saja aspek positif dan negatif pemberian remisi kepada narapidana korupsi. Adapun tujuan penelitian ini adalah untuk mengetahui hal hal yang menjadi pernasalahan dalam penelitian ini. Secara teoritis kegunaan dari penelitian ini adalah dalam rangka mendukung pembentukan dan pengembangan hukum dan secara praktis sebagai bahan masukan bagi para pemangku kepentingan antara lain Pemerintah, para ahli, akademisi, praktisi dan masyarakat.

\section{METODE PENELITIAN}

Metode yang digunakan dalam penelitian ini adalah normative empiris dengan cara menggabungkan penelitian kepustakaan dengan penelitian lapangan. Dengan demikian penelitian ini menggunakan baik data sekunder maupun primer. Data sekunder berupa bahan kepustakaan baik bahan primer beruapa peraturan perundangundangan dan bahan sekunder berupa buku buku yang relevan. Data primer didapat dari instansi terkait antara lain Ditjen Pemasyarakatan, KPK, ICW, Kepolisian, Kejaksaan, LSM dan Nara Pidana Korupsi. Data tersebut dikumpulkan dengan cara melakukan wawancara maupun melalui kuesioner. Kemudian data tersebut diolah dan kemudian dianalisis, kemudian disimpulkan dengan cara kualitatif. Penelitian ini dilaksanakan di DKI Jakarta, Medan dan Makassar pada tahun angggaran 2016.

\section{PEMBAHASAN}

\section{A. Pola Pemidanaan dan Kaitannya Dengan Pemberian Remisi}

Berdasarkan teori terdapat 3 jenis tujuan pemidanaan yaitu: Teori Pembalasan atau teori imbalan (Vergfalden) atau teori Absolut (Vergeldingstheorieen). Hukuman itu dijatuhkan sebagai pembalasan terhadap para pelaku karena telah melakukan kejahatan yang mengakibatkan kesengsaraan terhadap orang lain atau anggota masyarakat.(Leden Marpaung, 2009)

a. Teori ini membenarkan pemidanaan karena seseorang telah melakukan suatu tindak pidana, maka terhadap pelaku pidana mutlak harus diadakan pembalasan berupa pidana dengan tidak mempersoalkan akibat pemidanaan bagi terpidana.

b. Teori Relatieve (Nisbi) atau teori Tujuan (Doeltheorieen). Teori tujuan membenarkan pemidanaan (rechtsvaardigen), pada tujuan pemidanaan, yakni untuk mencegah 
terjadinya kejahatan (ne peccetur). Dengan adanya ancaman pidana dimaksudkan untuk menakut-nakuti calon penjahat yang bersangkutan atau untuk prevensi umum.

c. Teori Gabungan (Verenigings-theorieen). Teori ini mendasarkan pemidanaan pada perpaduan antara teori pembalasan dengan teori tujuan, karena kedua teori tersebut bila berdiri sendiri-sendiri, masing-masing mempunyai kelemahan (http://asasasashukumpidana.blogspot.com/, diakses 21 Maret 2016 pukul 14.00 WIB).

Teori Gabungan merupakan perpaduan dari Teori Absolut dengan Teori Relatif. Menurut Kartiman bahwa Teori Gabungan ini dibedakan dalam 3 (tiga) aliran sebagai berikut :

a) Teori Gabungan yang menitikberatkan pembalasan, tetapi dengan maksud sifat pidana pembalasan itu untuk melindungi ketertiban hukum;

b) Teori Gabungan yang menitikberatkan pada perlindungan masyarakat;

c) Teori Gabungan yang menitikberatkan sama antara pembalasan dengan perlindungan kepentingan masyarakat.

Tujuan pemidanaan yang termuat dalam pasal 47 rancangan KUHP Tahun 2008, berbunyi sebagi berikut :

a. Pemidanaan bertujuan untuk :

1) Mencegah dilakukannya tindak pidana dengan menegakkan norma hukum demi pengayoman masyarakat.

2) Memasyarakatkan terpidana dengan mengadakan pembinaan, sehingga menjadikan orang yang baik dan berguna;

3) Menyelesaikan konflik yang ditimbulkan oleh tindak pidana, memulihkan keseimbangan dan mendatangkan rasa damai dalam masyarakat;

4) Membebaskan rasa bersalah pada terpidana.

b. Pemidanaan tidak bermaksud untuk menderitakan dan tidak diperkenankan meremehkan martabat manusia

Dengan demikian dapat dikatakan bahwa pidana selalu mengandung unsur-unsur sebagai berikut : a. Pada hakikatnya merupakan suatu pengenaan penderitaan atau nestapa atau akibat-akibat lain yang tidak menyenangkan;

b. Diberikan dengan sengaja oleh orang atau badan yang mempunyai kekuasaan (yang berwenang);

c. Dikenakan kepada seseorang yang telah melakukan tindak pidana menurut UndangUndang.(Muladi dan Barda Nawawi Arief, 2005)

Tujuan penjatuhan pidana yang dianut Indonesia saat ini adalah kombinasi hukum Teori absolut dan relatif, yang berarti terdapat unsurunsur pejeraan yang dipadukan dengan pembinaan artinya bukan untuk balas dendam semata.Bentuk pelaksanaannya berupa upaya pelaksanaan pidana penjara yang berunsur kemanusiaan,dengan tujuan untuk memperbaiki perilaku dan moral. Apa bila dihubungkan dengan pemberian remisi kepada narapidana korupsi sesuai PP 99 tahun 2012 yang memperketat pemberian remisi, terjadi ketidakselarasan dengan tujuan pembinaan yang menginginkan agar narapidana tersebut dapat menyadari kesalahannya yang diwujudkan dalam perilaku yang lebih baik selama menjalani hukumannya dalam Lembaga Pemasyarakatan (LAPAS).

Dengan menerapkan PP 99/2012 maka sangat sedikit narapindana korupsi yang dapat mendapatkan remisi karena kesulitan dalam memenuhi syarat untuk mendapatkan remisi. Hal ini utamanya dialami oleh nara pidana korupsi yang jumlah uangnya sedikit. Dengan memberlakukan PP ini maka tidak bisa dibedakan antara koruptor kelas kakap dan kelas teri. Seperti diketahui banyak faktor yang menyebabkan orang korupsi, antara lain ada karena faktor keterpakasan umpanya dalam hal untuk mendapatkan proyek dari kantor pemerintah, kalau tidak memberikan sejumlah uang kepada pejabat di lingkungan kantor tersebut sulit untuk mendapat peroyek sehingga terjadi lah suap yang dilakukan oleh mereka dan terpaksa mengurangi kualitas atau mutu pekerjaan. Dapat juga karena perintah atasan atau tanggung jawab jabatan sehingga yang bersangkutan terjerat korupsi.

Dengan menjadikan korupsi sebagai kejahatan luar biasa tanpa membedakan jumlah uang yang dikorupsi maka terjadi perlakuan yang sama untuk semua pelaku tindak pidana korupsi padahal alasaan maupun jumlah uang yang 


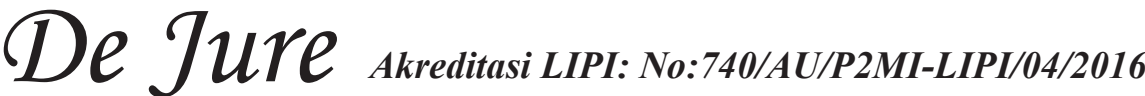

dikorupsi berbeda. Dalam hal suap mungkin saja tidak terjadi kerugian negara sama sekali akan tetapi ini dianggap juga sebagai kejahatan luar biasa dan disamakan dengan pejabat yang melakukan korupsi dengan jumlah uang yang sangat besar dan sudah pasti merugikan negara. Untuk itu perlu pembedaan antara pelaku tidak pidana korupsi. Seharusnya ada kasifikasi untuk menentukan apakah itu kejahatan luar biasa atau tidak. Hal ini juga dipandang tidak adil apabila dibandingkan dengan tindak pidana umum seperti pembunuhan berencana yang dilakukan dengan sangat keji akan tetapi mereka berhak mendapatkan remisi karena dianggap sebagai kejahatan biasa.

Hal ini dapat dibandingkan dengan seorang Responden eselon III yang menjadi responden di LP Tanjung Gusta Medan yang dituduh Korupsi tidak sampai 10 (sepuluh) juta rupiah akan tetapi dianggap sebagai kejahatan luar biasa dan pemberian remisinya diperketat sesuai dengan PP 99/2012. Hal ini dirasakan tidak adil oleh yang bersangkutan. Demikian juga denga seorang kontraktor yang dalam rangka persaingan untuk mendapatkan kontrak pekerjaan/proyek dari instansi pemerintah sehingga memberikan uang suap yang tidak terlalu besar kemudian ditangkap dan diadili kemudian dijatuhi hukuman 2 tahun 8 bulan penjara ditambah uang denda dan uang pengganti. Yang bersangkutan sulit mendapatkan remisi karena dikategorikan sebagai kejahatan luar biasa dengan demikian pengaturan mengenai pemberian remisinya juga tunduk kepada PP 99 tahun 2012.

Penyamaan semua tindak pidana korupsi sebagai kejahatan luar biasa telah menimbulkan ketidak adilan menurut para narapidana korupsi karena tidak memperhatikan motif maupun jumlah uang yang dikorupsi dan tidak memperhatikan apakah ada unsur kerugian negara apa tidak. Halhal tersebut di atas sudah mejadi pertimbangan hakim ketika mengadili suatu kasus korupsi itulah sebabnya mereka tidak mendapatkan hukuman yang sama ketika diadili didepan sidang. Akan tetapi ketika manjalani hukuman dalam rangka pembinaan di Lembaga Pemasayarakatan unsurunsur yang sudah dikemukana di atas tidak menjadi pertimbangan, dangan kata lain semua pelaku tindak pidana korupsi mempunyai perlakuan yang sama dan harus memenuhi persyaratan yang sama.
Dalam wawancara yang dilakukan terhadap para napi yang menjadi responden di Lembaga Pemasyarakatan maupun Rutan yang menjadi tempat penelitan yakni Lembaga Pemasyarakatan Cipinang, Makassar dan Makassar mengemuka keluhan para nara pidana atas diberlakukannya PP 99/2012 karena semua nara pidana tidak mempertimbangkan bobot korupsinya akan tetapi pembedaannya justru pada saat kapan narapidana tersebut mempunyai hukuman yang sudah mempunyai kekuatan hukum tetap yakni apakah sebelum atau sesudah PP 99/2012 mulai diberlakukan. Keluhan yang paling banyak adalah mengenai sulitnya untuk mendapatkan surat keterangan justice colaborator dan untuk membayar biaya pengganti dan denda. Pada umumnya mereka sudah tidak mempunyai uang yang cukup ketika masuk ke dalam Lembaga Pemasyarakatan baik karena sudah habis sebelum dijadikan terdakwa atau habis ketika mereka mencoba "mengurus" perkaranya ketika menjalani proses pemeriksaan sejak peniyidikan sampai putusan pengadilan.

Dalam pengurusan Justice Collaborator menurut mereka bisa didapatkan, dari hasil wawancara dengan mereka dapat diketahui bahwa mereka tidak memberikan uang ketika mengurus surat tersebut, akan tetapi ada kejanggalan dalam hal ini, karena mereka mendapat keterangan justice collaborator padahal dalam kasusnya dia hanya tersangka tunggal artinya pada kasus tersebut tidak ada tersangka lain yang didapat dari hasil kerjasama pemberian informasi dari yang bersangkutan. Pertanyaannya adalah dimana unsur collaboratornya.

Dari penelitian ini diketahui bahwa KPK selaku penyidik kasus korupsi sangat selektif dalam pemberian surat keterangan Justice collaborator dan berdasarkan data yang didapat KPK baru menerbitkan tujuh suratketerangan tersebut. Sedangkan Kejaksaan agak lebih mudah dalam mengeluarkan surat keterangan Justice Collaborator. Walaupun responden mengatakan bahwa mereka tidak memberikan uang untuk mendapatkan surat keterangan Justice Collaborator akan tetapi tidak mustahil bahwa penerbitan surat keterangan tersebut dapat menjadi sumber perbuatan korupsi yang baru berupa penyuapan untuk mendapatkan surat keterangan tersebut. Pemberlakuan PP 99/2012 juga dirasakan tidak adil oleh narapidana yang melakukan tindak 
pidana sebelum PP tersebut diperlakukan akan tetapi memperoleh putusan yang telah mempunyai kekutan hukum tetap setelah PP 99/2012 tersebut diberlakukan. Untuk mereka diberlakukan PP/2012 padahal mereka diadili sebelum PP tersebut berlaku akan tetapi baru mendapat hukuman yang mempunyai kekuatan hukum tetap setelah pemberlakuan PP 99/2012. Dalam hal ini ada perdebatan hukum karena hukum tidak boleh berlaku surut artinya karena perbuatan itu dilakukan sebelum PP99/2012 tersebut berlaku seharusnya mereka tunduk kepada PP 28/2006 .

Asas hukum adalah apa bila ada perubahan peraturan dalam suatu proses pidana yang sedang berlangsung maka yang diberlakukan adalah peraturan yang menguntungkan bagi tersangka atau terdakwa. Seharusnya hal ini juga menjadi pertimbangan ketika menerapkan PP 99/2012. Apakah diberlakukan bagi pelaku tindak pidana yang diadili setelah PP99/212 tersebut diberlakukan atau termasuk kepada terpidana yang melakukan tidak pidana sebelum PP2012/2012 tersebut diberlakukan akan tetapi mendapatkan putusan yang mempunyai kekuatan kukum tetap ketika PP/99 tersebut sudah diberlakukan.

Seorang narapidana merasa diperlakukan tidak adil kerena pada saat PP 99/2012 diberlakukan dia sedang menunggu putusan kasasi padahal dia di vonnis di Pengadilan Negeri sebelum, PP 99 diberlakukan. menurut yang bersangktan seandainya dia tau akan ada PP 99/2012 mungkin dia tidak akan nengajukan Kasasi sehingga dia mendapatkan remisi sesuai dengan PP 28/2006. Dengan demikian perlu diadakan peninjauan ulang terhadap PP 99/2012 apabila tidak dicabut dan dikembalikan seperti PP 28 paling tidak ada revisi mengenai kepada siapa saja PP ini diberlakukan khususnya dalam Tindak Pidana Korupsi dengan memepertimbangkan jumlah uang yang dikorupsi dan jabatan atau status terpidana. Pelaku tindak pidana korupsi yang terdorong melakukan tindak pidana suap agar mendapatkan pekerjaan atau karena perintah atasan dan tanggung jawab jabatan terlibat tindak pidana korupsi harusnya dibedakan dengan seorang pejabat yang karena kewenangannya melakukan korupsi dengan jumlah yang besar dan merugikan keuangan negara. Saat ini muncul berita di televisi bawa KPK tidak setuju sesuai dengan adanya revisi terhadap PP 99 dan menginginkan agar tidak diberikan remisi terhadap koruptor hal ini sesuai juga dengan jawaban KPK selaku salah satu responden dalam penelitan ini. Hal ini dapat dimaklumi karena kasus yang ditangani KPK adalah kasus-kasus korupsi besar yang dilakukan oleh pejabat pejabat tinggi atau melibatkan uang yang cukup besar.

Berbeda dengan para pelaku tindak pidana yang diadili setelah diproses oleh kejaksaan yang dapat menangani semua jenis korupsi termasuk korupsi kecilan-kecilan akan tetapi karena sial mereka tertangkap. Dalam pemberian remisi seharusya ada pembedaan antar para pelaku tindak pidana ini dalam hal pemberian remisi seperti juga hakim mempertimbangkan unsur unsur ini ketika mengadili para terdakwa sebelum menjadi terpidana. Pertimbangan pertimbangan ini juga seharusnya dimasukkan dalam Peraturan yang mengatur pemberian remisi khususnya terhadap koruptor.

Dengan sulitnya mendapatkan remisi bagi narapidan korupsi maka akan menimbulkan rasa frustrasi bagi para narapidana tersebut. Mereka merasa bahwa percuma berkelakuan baik karena tidak akan mendapat remisi disebabkan tidak dapat memenuhi syarat-syarat yang ditentukan dalam PP 99/2012. Hal ini mempersulit pembinaan yang dilakukan oleh lembaga pemasyarakatan, karena harus membina para nara pidana yang sudah dalam kedaaan steress dan frustrasi yang punya potensi untuk menimbulkan kerusuhan. Peneliti menemukan responden seorang pengusaha yang menjadi narapidana yang sama sekali tidak percaya lagi kepada hukum di Indonesia dan hanya menanyakan bagaimana caranya untuk keluar dari WNI dan menjadi WNA. Salah satunya adalah dengan diberlakukan nya PP 99/2012 tersebut.

Perdebatan mengenai pemeberian remisi kepada koruptor masih menimbulkan pro dan kontra lembaga- lembaga penegak hukum pun tidak selalu mempunyai suara yang sama. Demikian juga lembaga swadaya masyarakat ada yang mengatakan bahwa pemberian Remisi tidak boleh diskriminatif tapi ada juga yang mengatakan bahwa PP 99/2012 yang memperketat pemberian remisi itu sudah tepat. Semua pendapat tersebut mempunya alasan masing masing. Dari hasil wawancara dan kuesioner yang diedarkan terdapat beberapa lembaga pengak hukum seperti KPK dan Kejaksaan yang menginginkan bahwa Remisi harus diperketat bagi semua koruptor tanpa pandang bulu, Kepolisian berpendapat bahwa untuk koruptor kelas berat memang harus 


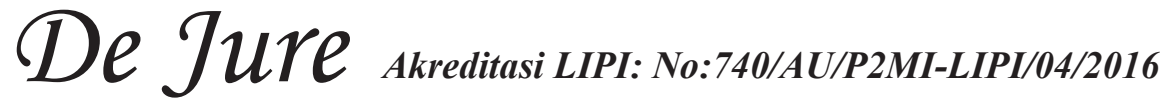

diperketat akan tetapi untuk koruptor yang karena tanggung jawab jabatan atau jumlah korupsiya kecil dapat diberikan remisi seperti narapiadana lainnya. Sedangkan dari phak LSM umpanya ICW tidak setuju kalau remisi diberikan kepada koruptor sedangkan dari kelompok pengacara menytakan bahwa remisi harus diberikan karena itu adalah hak.

Pihak yang setuju melihat bahwa pemberian hukuman penjara adalah sebagai balas dendam atas perbuatan narapidana oleh karena itu harus dihukum berat agar menimbulkan efek jera. Akan tetapi ada juga yang berpendapat bahwa hukuman tersebut bukan semata mata untuk membalas dendam akan tetapi juga menonjolkan unsur pembinaan. Sesuai dengan sistim pemidanaan yang dianut di Indonesia maka sebaiknya unsur penjeraan dengan cara memasukkan nara pidana ke dalam penjara untuk dibina sudah tepat. Salah satu dari hasil pembinaan tersebut ada apabila nara pidana yang bersangkutan berkelakuan baik.

Tentunya dengan berkelakuan baik mereka berhak mendapat remisi seperti narapidana lainnya sesuai dengan Undang Undang nomor 12 Tahun 1995 tentang Pemasyarakatan yang menentukan bahwa remisi itu dalah hak. Di atas sudah diuraikan bahwa pengetatan syarat untuk mendapat kan remisi bagi koruptor dengan PP 99/2012 ternyata dalam prakteknya menimbulkan kesulitan bagi nara pidana maupun lembaga pemasayarakatan. Dengan demikian selayaknya Pemerintah meninjau ulang keberadaan Peraturan Pemerintah tersebut.

\section{B. Prosedur dan Pelaksanaan Pemberian Remisi kepada Narapidana Korupsi}

\section{Gambaran Umum Pelaksanaan}

Pelaksanaan pemberian remisi kepada narapidana korupsi sebelum ditetapkan PP 99 Tahun 2012, diberikan berdasarkan PP No. 28 Tahun 2006, namun setelah ditetapkannya PP No. 99 tahun 2012, maka pemberian remisi terhadap narapidana korupsi berdasarkan PP tersebut (setelah tgl 12 November 2012), ketentuan tersebut didasari oleh SE Menteri Hukum dan HAM No. M.HH-04.PK.01.05.06 Tahun 2013 tentang petunjuk pelaksanaan pemberlakuan PP No. 99 Tahun 2012. Dengan adanya SE Menkumham tersebut tidak semua narapidana korupsi dikenakan PP 99 Tahun 2012.
Berdasarkan norma yang berlaku, kewenangan pemberianremisi, asimilasiatau dan pembebasan bersyarat bagi narapidana khususnya terhadap pelaku tindak pidana korupsi adalah kewenangan yang melekat pada Kementerian Hukum dan Hak Asasi Manusia/ LAPAS sebagaimana yang diatur dalam PP 99 tahun 2012 tentang perubahan kedua atas Peraturan Pemerintah Nomor 32 Tahun 1999 tentang syarat dan Tata Cara Pelaksanaan Hak Warga Binaan Pemasyarakatan/ Narapidana yang tercantum dalam Pasal 34B dan 34 Pasal 34A dan 34A angka 3 terhadap narapidana yang telah memenuhi persyaratan sebagaimana yang tercantum dalam pasal 34, 34 A huruf a dan b. Bahwa untuk pemberian remisi yang dilakukan Kementerian Hukum dan Hak Asasi Manusia/ Lapas tersebut masih memerlukan surat keterangan sebagai kelengkapan prosedural dari tugas serta fungsi kewenangan dari instansi kejaksaan yaitu dalam hal:

1) Surat keterangan dari instansi kejaksaan yang menerangkan apakah narapidana tersebut masih ada perkara lain (korupsi) atau tidak; dan

2) Surat keterangan atau bukti pembayaran uang denda dan pembayaran uang pengganti; atau

3) Surat keterangan yang dilampirkan pernyataan dari narapidana yang menyatakan ketidaksanggupan untuk membayar utang denda dan uang pengganti; atau

4) Surat keterangan atau bukti lain yang menyatakan bahwa narapidana tersebut telah melunasi pembayaran uang denda atau uang pengganti yang berasal dari hasil penyitaan harta terpidana untuk pembayaran uang denda atau uang pengganti yang berasal dari hasil penyitaan harta terpidana untuk pembayaran uang denda dan uang pengganti (pasal 18 UU 31 tahun 1999) berdasarkan pelaksanaan putusan pengadilan/eksekusi uang denda dan uang pengganti yang merupakan syarat mutlak yang harus dipenuhi narapidana untuk mendapat remisi sesuai ketentuan pasal 34A huruf $b$.

Selain surat keterangan pembayaran uang denda dan uang pengganti ada surat keterangan yang dibuat oleh instansi kejaksaan/penyidik yang menerangkan terpidana saat menjalani proses penyidikan adalah sebagai justice collabolator yang dilampirkan surat pernyataan dari yang bersangkutan secara tertulis untuk bersedia dengan 
penegak hukum untuk membantu membongkar perkara tindak pidana yang dilakukan, hal tersebut sebagai hal yang bisa dipertimbangkan untuk mendapat remisi (Pasal 34 A huruf a dan Pasal 34 A angka 3).

Dalam praktik di lapangan, permasalahan utama dalam pelaksanaan PP 99/2012 adalah diikutsertakannya lembaga terkait (seperti: BNN, Kepolisian, dan Kejaksaan) dalam menentukan apakah seseorang terpidana berhak mendapatkan remisi dan /atau pembebasan bersyarat. Hal ini terkait dengan persyaratan yang harus melengkapi persyaratan surat kesediaan bekerjasama dengan penegak hukum serta prosedur permohonan rekomendasi/pertimbangan tertulis. Padahal, sesuai dengan ketentuan dalam UU No. 12 Tahun 1995, setiap warga binaan berhak mendapat remisi dan pembebasan bersyarat selama memenuhi ketentuan dan persyaratan yang berlaku. Lebih lanjut, data lapangan juga menggambarkan bahwa prosedur pelaksanaan pemberian remisi terhadap narapidana korupsi sesudah ditetapkannya PP Nomor 99 Tahun 2012 kerap menimbulkan kesulitan prosedural yang juga berdampak langsung terhadap perlindungan hak narapidana tindak pidana korupsi.

\section{Problematika Justice Collaborator}

Berdasarkan data lapangan, salah satu aspek yang disoroti dalam pelaksanaan pengetatan remisi ialah terkait persyaratan justice collaborator. Berkaitan dengan hal tersebut, pihak LAPAS pernah meminta surat tersebut sebagai salah satu syarat untuk diberikan remisi, namun pada praktiknya, banyak aparat penegak hukum yang belum memahami substansi PP Nomor 99 Tahun 2012 secara menyeluruh. Aparat juga kerap tidak mengetahui konsep justice collaborator yang di kehendaki secara normatif dalam PP tersebut.

Konsepjustice collaborator dalam pandangan KPK sesuai dengan SEMA RI No. 4 tahun 2011 tentang Perlakuan bagi pelapor tindak pidana dan saksi pelaku yang bekerjasama di dalam perkara tindak pidana tertentu.

Dalam praktinya, pada tahun 2015 KPK mengeluarkan status JC untuk 7 orang. KPK hanya menangani justice collaborator terhadap pelaku yang sedang ditangani oleh KPK, dengan demikan KPK tidak akan menerbitkan status justice collaborator apabila kasus ditangani oleh Kejaksaan ataupun Kepolisian. KPK hanya memberikan surat keterangan justice collaborator setelah persidangan selesai. Jadi sampai dengan putusan pengadilan tidak ada intervensi dari penegak hukum lain terhadap Kementerian Hukum dan HAM, dan fungsi pemasyarakatan baru muncul pasca putusan pengadilan.

Terkait dengan proses pemberian remisi. Dari empatpuluh delapan narapidana korupsi yang dijadikan sampel, sebagian besar (28 orang) memberikan jawaban terlalu berbelit-belit , 8 orang tdk mudah dan 2 orang mudah. Selain itu, terkait dengan kendala dalam proses pemberian remisi, sebanyak 21 orang napi menjawab ada kendala, mengingat lokasi jauh dari pusat, dan 10 orang tidak ada kendala dan sangat subjektif 18 orang.

Terkait dengan penilaian/ kriteria berkelakuan baik. sebanyak 20 orang menjawab sangat jelas sedangkan 14 orang lagi memberikan jawaban sangat sujektif dan 5 orang tidak jelas, sisanya belum memperoleh remisi. Sedangkan berkaitan dengan adanya persyaratan napi untuk memperoleh justice collaborator. Jawaban yg diberikan 25 orang merasakan mempersulit napi untuk mendapatkan remisi dan 16 orang napi tidak mempersulit, sisanya tidak tahu.

\section{Analisis Pelaksanaan dalam Perspektif Hukum}

Kebijakan Pemerintah atas Remisi bagi tindak pidana korupsi menimbulkan polemik di masyarakat, baik Pemerintah sebagai pembuat kebijakan, badan legislatif, lembaga negara maupun pengamat hukum dari kalangan praktisi dan akademisi. Betapa tidak, persoalan remisi adalah persoalan mendasar yang berkaitan dengan Hak Asasi Manusia, yaitu hak narapidana untuk memperoleh pengurangan hukuman, yang memang diakui secara universal di dunia. Haruslah diakui bahwa persoalan korupsi sebagai kejahatan yang serius merupakan beban berat bagi setiap negara, namun demikian seluruh konvensi korupsi juga mempertimbangkan untuk menghindari adanya diskriminasi pemidanaan terhadap narapidana, tanpamembedakannarapidanadaripemidanaandan jenis tindak pidananya. Dunia memahami bahwa persoalan korupsi merupakan persoalan dunia, sehingga diakhir abad 20 ini sebagai melinium ketiga ditandai dengan bermunculan beraneka konvensi dunia tentang korupsi. Munculnya aneka konvensi ini menandai bahwa kesamaan pesan UN Convention Against Corruption 2003, meski tidak memakai istilah korupsi sebagai "Extra 


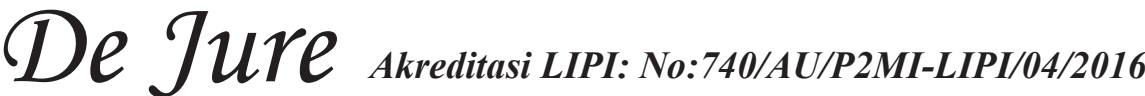

Ordinary Crimes", menyebut korupsi sebagai "the seriousness of problem", juga "...threat to the sustainable development of people”. Imbasnya adalah polemik bahwa Indonesia merupakan negara nomor satu terkorup di Asia dan nomor tiga terkorup di dunia, sehingga merupakan suatu kewajaran timbul polemik pencitraan kekuasaan terhadap issue korupsi, yaitu Moratorium Remisi.

Anehnya munculnya aneka konvensi dunia, seperti Inter-American Convention Against Corruption 1996, ataupun The Criminal Law Convention on Corruption 1999, juga memiliki kesimpulan menghendaki adanya suatu balanced between punishment and protection of human rights, termasuk hak para narapidana, sama sekali tidak pernah mempermasalahkan moratorium remisi. Indonesia sebagai negara beradab yang telah mengakui dan meratifikasi Konvensi Perserikatan Bangsa Bangsa, UN Convention Against Corruption 2003 (UNCAC 2003) melalui UU No.7 Tahun 2006, akan mematuhi substansi, termasuk didalamnya aturan mengenai pemidanaan dan rehabilitasi narapidana. Polemik publik tentang moratorium remisi bagi pelaku tindak pidana korupsi inilah yang menjadi sorotan hangat sebagai soal pelanggaran HAM, sejalan arah politik pencitraan kekuasaan ataukah memang sesuai dengan prinsip legalitas kebijakan Negara. muncul polemik pengetatan remisi, sehingga diperlukan beberapa catatan, baik dari sisi sistem pemidanaan dan politik hukum.

Pertama, dari sisi sistem pemidanaan, perlu dipahami, bagi seseorang yang telah diputuskan bersalah melakukan tindak pidana oleh pengadilan yang berkekuatan tetap, apapun jenis tindak pidananya, pada saat itu pelaku berstatus narapidana. Sejak berstatus narapidana, sesuai sistem pemidanaan, narapidana memiliki hak mendasar sebagai hak asasi yang sama, tanpa adanya diskriminasi pemidanaan, suatu equal rights without punishment discrimination, untuk memperoleh remisi sebagai hak. Dengan demikian, haruslah dihindari suatu pelanggaran diskrimisasi pemidanaan dengan menerbitkan suatu moratorium remisi antara jenis tindak pidana korupsi yang memperoleh remisi, dan yang tidak memperoleh remisi.

Jika dilihat dari konsep mengenai Remisi yang kemudian mendunia dikenal sebagai "Remission" (a pardon granted for an offence), dan di Indonesia sebagai pemberian Remisi yang diatur pada Pasal 14 ayat (1) huruf i UU No. 12 tahun 1995 tentang Pemasyarakatan berikut Peraturan Pemerintah (PP) sebagai aturan pelaksanaanya tidak mengenal diskriminasi pemidanaan maupun jenis tindak pidananya. Secara universal, manakala kita membicarakan pemberian, apakah yang dinamakan Remisi, Asimilasi, Cuti Kunjungan Keluarga, Cuti Menjelang Bebas dan Pembebasan Bersyarat (Parole), berarti kita mengakui konteks pendekatan sistem pemidanaan yang dinamakan "Rehabilitation Theory", bukan Deterrence Effect Theory. Tujuan utama rehabilitasi adalah dengan cara memperbaiki pola tingkah laku yang baik dari para narapidana agar kembali dapat bersosialisasi pada kehidupan normal dan sewajaranya. Pada pemaknaan ini, teori deterrence effect (efek jera) telah ditinggalkan sejak abad 19 memasuki abad 20, karena konsep efek jera lebih dianggap sebagai pendekatan balas dendam yang tidak manusiawi dan politis (political revenge), kanibalistik dan melanggar hak asasi manusia. Dikatakan sebagai pelanggaran hak asasi manusia, karena pengurangan hak narapidana dari konsep rehabilitasi merupakan pelanggaran atas "non derogable rights”, yaitu suatu hak (narapidana) yang tidak dapat dikurangi dengan alasan, kondisi dan kekecualian apapun, apakah negara dalam keadaan perang (state of war), instabilitas politik dalam negeri (interna political instability) atau kondisi darurat publik (public emergency). Pengurangan hukuman, apapun istilahnya dengan pembatasan atau pengetatan, diartikan sebagai pola pendekatan efek jera yang berbau political revenge, kanibalistik, tidak manusiawi sifatnya, dan menimbulkan diskriminasi pemidanaan, baik terhadap sistem maupun jenis tindak pidananya. Dari pengalaman sejarah, penempatan pelaku tindak pidana dengan teori efek jera ternyata justru menempatkan manusia pada jurang kehancuran dan menjauhkan kehidupannya dari lingkungan keluarga dan masyarakat, karena itu hingga kini konsep yang berkeprikemanusian dengan teori rehabilitasi melalui clinical treatment yang diterima secara universal dari semua sistem pemidanaan di dunia, termasuk di Indonesia.

Dari sisi politik hukum, legalitas hak mendasar pemberian remisi bagi narapidana adalah Pasal 14 ayat 1 huruf i UU No. 12 tahun 1995 tentang Pemasyarakatan berikut Peraturan Pemerintah sebagai aturan pelaksanaanya (terakhir dengan PP No. 28 Tahun 2006), dengan demikian acuan terletak pada UU No. 12 tahun 
1995, khususnya Pasal 14 ayat 1 huruf i, karena Remisi merupakan suatu hak yang absolut dan non-derogable, tiada kondisi eksepsional yang dapat mengurangi hak tersebut, apakah dalam bentuk dan cara pengurangan atau pembatasan. Memang telah dilakukan perubahan tentang remisi melalui Pasal 34 ayat 3 PP No. 28 tahun 2006 dengan menunjuk delik terorisme, narkotika/ psikotropika, korupsi, keamanan negara, hak asasi manusia yang berat, transnasional terorganisasi, tetapi pada PP tersebut hanya mensyaratkan pemberian remisi bila berkelakuan baik dan telah menjalani $1 / 3$ masa pidana, sedangkan kalimat “...perlu disesuaikan dengan dinamika dan rasa keadilan masyarakat" hanya ada pada Penjelasan Umum PP tersebut, bukan pada Penjelasan Pasal 34 ayat 1 PP yang dinyatakan "cukup jelas", begitu pula pembatasan bagi whistle blower dan collaborator penegak hukum sama sekali tidak tercantum dalam PP tersebut. Berdasarkan asas Lex Certa, syarat remisi pada ketentuan pasal 34 ayat 1 PP tidak dapat diartikan secara multiinterpretatif sebagai rasa keadilan masyarakat untuk memperoleh justifikasi legalitas.

Perlu juga mendapat perhatian bahwa Pasal 34 ayat 3 PP ini yang substansial membatasi hak narapidana seharusnya tidak boleh bertentangan dengan Pasal 14 ayat 1 huruf i UU No.12 tahun 1995 karena dapat dianggap melanggar asas Lex Superiori derogat Legi Inferiori sesuai Pasal 7 ayat (5) UU No. 10 tahun 2004 tentang Pembentukan Peraturan Perundang-undangan yang menegaskan bahwa secara hierarki peraturan perundang-undangan yang lebih rendah (PP) tidak boleh bertentangan dengan peraturan perundangundangan yang lebih tinggi (UUD/UU). Perubahan pengetatan remisi melalui PP memang dibenarkan, tapi masalahnya apakah perubahan sesuai prinsip legalitas ataukah bertentangan dengan hukum. Bahkan Pasal 30 butir 5 UN CAC 2003 (diratifikasi Indonesia dengan UU No.7 Th 2006) adalah imperatif sifatnya, yaitu Indonesia wajib mempertimbangkan bagi narapidana suatu "early release or parole", suatu remisi atau pembebasan bersyarat.

Berdasarkan logika di atas, pemberian remisi kepadanarapidanatindakpidanakorupsimerupakan sebuah open legal system, yakni pemerintah diberikan keleluasaan untuk menentukan margin dalam memberikan remisi. Mengingat konsep filosofis dan perkembangan norma terkait tindak pidana korupsi di tingkat internasional, sudah sepatutnya intervensi pemerintah terhadap pelaku tindak pidana korupsi didasarkan pada basis ilmiah yang objektif dan dapat dipertanggung-jawabkan dalam rangka proses pemasyarakatan narapidana tersebut.

Dengan demikian, intervensi ini justru dapat dilihat sebagai perlindungan HAM bagi pelaku, dalam hal ini narapidana tindak pidana korupsi, dan masyarakat luas, dalam konteks mencegah terjadinya pengulangan tindak pidana. Berbagai persyaratan secara prosedural di dalam PP 99/2012 merupakan bentuk intervensi negara yang lebih menekankan pada prilaku yang tampak, misalnya: membuat pernyataan justice collaborator yang pada praktiknya bisa dimanipuasi. Intervensi demikian sesungguhnya masih sangat sederhana dan kurang menjamin kepastian hukum, ketimbang berbagai invertensi di negara-negara maju yang dalam pelaksanannya melibatkan psikolog, psikiater untuk melihat perubahan napi berdasarkan catatan di Lapas (jawaban beraturan atau tidak dan lain sebagainya). Berdasarkan hasil assessment tersebut kemudian seorang narapidana dapat direkomendasikan untuk mendapatkan remisi atau tidak.

\section{Fungsi Pengawasan Dalam Pelaksanaan pemberian Remisi narapidana korupsi}

Dalam perspektif hukum, tujuan pengawasan untuk menghindari terjadinya keliruan - keliruan, baik yang sengaja maupun tidak sengaja, sebagai sesuatu usaha preventif, atau juga untuk memperbaiki apabila sudah terjadi keliruan itu, sebagai suatu usaha represif. Dalam praktik adanya kontrol itu sering dilihat sebagai sarana mencegah timbulnya segala bentuk penyimpangan tugas pemerintahan dari apa yang telah digariskan. Memang disinilah letak inti atau hakekat pengawasan. (Paulus E Lotulung, 1986)

Sebagaimana telah di uraikan pada bab sebelumnya, bahwa pengawasan narapidana secara umum di LAPAS/RUTAN dapat dilakukan, baik secara internal maupun eksternal (termasuk pengawasan pemberian remisi narapidana korupsi).

\section{a. Pengawasan Internal}

Pengawasan internal ini pada dasarnya dilakukan oleh Ditjen Pemasyarkatan yang dalam pelaksanaannya didelegasikan kepada Kantor Wilayah Kemenkumham, demikian 
pula dalam lingkup LAPAS sendiri ada juga pengawasan yang disebut dengan pengawasan melekat, yaitu Pelaksanaan pengawasan melekat sebagai alat utama untuk memberikan jaminan kualitas (quality assurance) penyelenggaraan pemerintahan dilakukan secara berjenjang di setiap UPT Lembaga Pemasyarakatan, mulai dari Kepala, Kabag/kasubag TU, Kepala Bidang sampai ke Kepala seksi/kepala sub seksi dan pegawai/ staff yang dilakukan sesuai aturan yang ada. Dalam pengertian bahwa kewajiban pimpinan organisasi dalam melakukan evaluasi terhadap kinerja bawahannya dilakukan secara terus menerus dimana hasil penilaian ini dituangkan dalam penilaian pelaksanaan pekerjaan. Permasalahannya adalah seberapa jauh efektifitas pengawasan melekat atau pengawasan atasan langsung terhadap kegiatan yang dilaksanakan oleh unit kerja yang berada di bawahnya mengingat masih adanya kecenderungan untuk melindungi korps yang masih cukup tinggi.

Kenyataan bahwa hak-hak narapidana masih begitu samar-samar dan mengutip pendapat Mardjono Reksodiputro bahwa terdapat diskresi yang terlalu besar dalam memperlakukan narapidana dalam Lembaga Pemasyarakatan. Terbukti dengan dikeluarkannya moratorium terhadap hakhak narapidana korupsi berupa pencabutan SK Pembebasan Bersyarat dan permasalahan yang dialami narapidana korupsi di LAPAS Kelas 1 Makassar dan di LAPAS Kelas 1 Tanjung Gusta Medan yang ditemukan tim. Tidak tertutup kemungkinan masih banyak hal serupa yang terjadi di UPT Lembaga Pemasyarakatan dan Rumah Tahanan Negara di seluruh Indonesia (Mardjono Reksodiputro, 2009).

Sebenarnya terdapat beberapa alternatif penyelesaian yang dapat dipakai terhadap masalah tersebut. Pembentukan Balai Pertimbangan Pemasyarakatan (BPP) dan Tim Pengamat Pemasyarakatan (TPP) di tiap tingkatannya (Pusat, Wilayah dan Daerah) bukan tanpa maksud. Balai Pertimbangan Pemasyarakatan (BPP) dan Tim Pengamat Pemasyarakatan (TPP) yang dibentuk dalam melakukan tugas dan fungsinya bisa dikatagorikanmasuk dalamranah pengawasan (cetak Biru Lembaga Pemasyarakatan, Departemen Hukum dan Hak Asasi Manusia, 2009). TPP Daerah misalnya, yang berada di setiap Unit Pelaksana Teknis Pemasyarakatan berdasarkan Pasal 14 Ayat (3) Huruf-d Keputusan Menteri Hukum dan Perundang-undangan Nomor: M.02. PR.08.03 Tahun 1999 mempunyai tugas untuk menerima keluhan dan pengaduan dari Warga Binaan Pemasyarakatan untuk kemudian meneruskannya kepada Kepala UPT terkait. Apabila dilihat darisusunan keanggotaan TPP Daerah juga tidak hanya berasal dari internalpihak UPT sendiri melainkan juga melibatkan unsur dari luar UPT sepertiHakim Pengawas dan Pengamat Hakim Wasmat)danbadandanatauperorangan yang berminat terhadap pembinaan (Pasal 16 Ayat (3) Keputusan Menteri Hukum dan Perundang-undangan Nomor : M.02. PR.08.03 Tahun 1999 tentang Pembentukan Balai Pertimbangan Pemasyarakatan dan Tim Pengamat Pemasyarakatan) . Melihat tata kerja dari TPP sendiri paling tidak terdapat 2 macam sidang yang dilakukan, yaitu :

a) Sidang Rutin, yaitu sidang TPP yang dilaksanakan sekurang-kurangnya 2 (dua) kali dalam 1 (satu) bulan. Sidang rutin ini membahas perkembangan pelaksanaan teknis pembinaan dan pembimbingan WBP sesuai pentahapan proses pemasyarakatan.

b) Sidang Khusus, yaitu sidang TPP yang dilaksanakan dan berlangsung setiap waktu sesuai kebutuhan pembinaan dan membahas persoalan-persoalan yang menyangkut pelaksanaan teknis Pembinaan dan Pembimbingan WBP yang memerlukan penyelesaian cepat ( Pasal 20 Ayat (1) dan (2) Keputusan Menteri Hukum dan Perundangundangan Nomor : M.02. PR.08 .03 Tahun 1999 tentang Pembentukan Balai Pertimbangan Pemasyarakatan dan Tim Pengamat Pemasyarakatan).

Dan tentang remisi termasuk dalam materi sidang TPPdimana pada Pasal 22 Ayat (1) disebutkan :

"Semua usulan materisidang TPP untuk bahan pembinaan dan pembimbingan WBP baik mengenai usulan Asimilasi, 
Cuti Mengunjungi Keluarga, CutiMenjelang Bebas, Pembebasan Bersyarat, Remisi, Penempatan, Mutasi dan lain sebagainya harus sudah memenuhi syarat substantif dan administratif sebagaimana yang ditetapkan dalam pentahapan pembinaan sesuai ketentuan proses pemasyarakatan ".

Untuk sidang TPP sendiri dianggap sah apabila dihadiri oleh sekurangkurangnya 2/3 (dua pertiga) dari jumlah anggota dan dalam pelaksanaan sidang, baik sidang rutin maupun sidang khusus harus diadakan notulen serta dicatat secara jelas setiap usulusul dari setiap anggota yang hadir ( Pasal 21 Ayat (1) Keputusan Menteri Hukum dan Perundang-undangan Nomor: M.02. PR.08.03 Tahun 1999 tentang Pembentukan Balai Pertimbangan Pemasyarakatan dan Tim Pengamat Pemasyarakatan). Dan setiap persetujuan/keputusan sidang TPP didasarkan kepada musyawarah dan mufakat. Apabila musyawarah dan mufakat tidak tercapai, maka dilakukan pemilihan dengan suara terbanyak dengan ketentuan bahwa keputusan diambil lebih dari setengah ditambah 1 (satu) ( Pasal 25 Ayat (2) dan (3) Keputusan Menteri Hukum dan Perundang-undangan Nomor : M.02. PR.08.03 Tahun 1999 tentang Pembentukan Balai Pertimbangan Pemasyarakatan dan Tim Pengamat Pemasyarakatan).

Berdasarkan hasil wawancara yang dilakukan dengan Lembaga Pemasyarakatan Makassar dan Medan yang menyatakan minimnya kedatangan Hakim Wasmat ke Lembaga Pemasyarakatan. Kedatangannya hanya 1 (satu) kali dalam kurun waktu satu tahun. Dari kedua keterangan tersebut tim menyimpulkan bahwa melihat komposisi keanggotaan TPP Daerah sendiri yang didominasi oleh orang-orang yang berada dalam struktur organisasi UPT Lembaga Pemasyarakatan,makatanpakehadiranHakim Wasmat maupun badan atau perorangan yang berminat terhadap pembinaan sebagai anggota dari TPP Daerah maka sidang TPP tetap dapat dilaksanakan dan dianggap sah karena telah dihadiri oleh 2/3 dari TPP Daerah ( Berdasarkan Pasal 16 Ayat (3) Keputusan Menteri Hukum dan Perundang- undangan Nomor M.02.PR.08.03 tahun 1999 TPP Lembaga Pemasyarakatan Kelas I terdiri dari Ketua Merangkap Anggota, Sekretaris merangkap anggota dan 12 anggota dimana hanya 2 anggota yang berasal dari luar UPT yaitu Hakim Pengawas dan Pengamat serta Badan dan atau perorangan yang berminat terhadap pembinaan) .

Apabila dalam sidang TPP Daerah keberadaan Hakim Wasmat dapat diefektifkan sehingga sidang tidak hanya didominasi dengan kehadiran anggota intern UPT Lembaga Pemasyarakatan maka sidang TPP dapat menjadi lebih transparan. Paling tidak terdapat upaya untuk meminimalkan timbulnya rumor "pungli" dalam pemberian remisi bagi narapidana. Dilain pihak, apabila sidang Rutin TPP yang sedianya dilaksanakan sekurang-kurangnya 2 (dua) kali dalam 1 (satu) bulan sesuai aturan tersebut diatas maka kejadian yang dialami narapidana tindak pidana korupsi yang lain sangat kecil kemungkinan untuk terjadi.

Sementara itu, keberadaan Balai Pertimbangan Pemasyarakatan (BPP) juga dirasa belum menampakkan hasil maksimal karena selama ini Balai Pertimbangan Pemasyarakatan (BPP) hanya memberikan saran dan pertimbangan kepada Menteri. Hasil tersebut juga tidak terpublikasi atau menjadi dokumen yang dapat diakses oleh masyarakat.Terkait dengan kinerja Balai Pertimbangan Pemasyarakatan (BPP), aspek yang juga memberikan kontribusi terhadap kurang optimalnya kinerja Balai Pertimbangan Pemasyarakatan (BPP) adalah terkait dengan kesibukan serta aktivitas dari anggotanya yang cukup tinggi sehingga sulit diantara anggota BPP (Susunan Keanggotaan BPP berdasarkan Keputusan Menteri Hukum dan Perundang-undangan Nomor M.02. PR.08.03 Tahun 1999 tentang Pembentukan Badan Pertimbangan Pemasyarakatan dan Tim Pengamat Pemasyarakatan terdiri atas:

a) Para Ahli di bidang Pemasyarakatan,

b) Wakil Instansi Terkait,

c) Wakil Lembaga Swadaya Masyarakat dan

d) Tokoh Masyarakat yang memiliki rasa kepedulian terhadap pembinaan Warga 


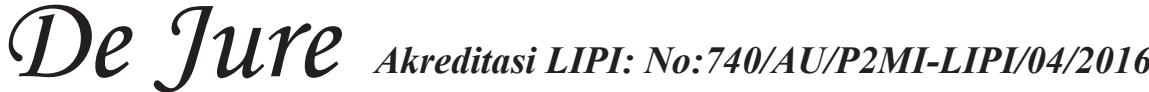

Binaan Pemasyarakatan) untuk dapat duduk bersama membicarakan dan memberikan solusi terhadap proses perbaikandalambidangpemasyarakatan. Karena koordinasi yang lemah maka kunjungan-kunjungan dalam rangka pengawasan dan menampung setiap permasalahan yang mengemuka ditiap UPT Pemasyarakatan tidak dapat berjalan sesuai dengan yang diinginkan.

Kondisi tersebut dapat menjadi dasar argumentasi untuk merevitalisasi peran dan fungsi Balai Pertimbangan Pemasyarakatan (BPP) agar lebih efektif dan memiliki dampak yang konkrit serta sebagai upaya untuk menciptakan check and balances. Reposisi Balai Pertimbangan Pemasyarakatan (BPP) dapat diarahkan sebagai cikal bakal lahirnya Komisi Pemasyarakatan yang bersifat independent. tentunya dengan melakukan revisi pada regulasi atau ketentuan Undangundang misalnya UU No 12 tahun 1995 tentang Pemasyarakatan dan Keputusan Menteri Hukum dan Perundang-Undangan Republik Indonesia Nomor: M.02.Pr.08.03 Tahun 1999 Tentang Pembentukan Balai Pertimbangan Pemasyarakatan Dan Tim Pengamat Pemasyarakatan.

Konsep BPP dan TPP dalam Undang-Undang Pemasyarakatan, setelah "meninggalkan" program Lembaga Hakim Wasmat menurut KUHAP, dalam praktiknya ternyata kurang berfungsi. Sementara program Lembaga Hakim Wasmat juga telah "dimandulkan" oleh Undang-Undang Pemasyarakatan, sehingga ketiga lembaga pengawasan tersebut menjadi lembaga pengawasan yang banci. Menguatkan program BPP dan TPP berarti membunuh karakter Hakim Wasmat, konsekuensi logisnya ialah harus menghapus program Hakim Wasmat dari KUHAP, sedangkan menghidupkan kembali peranan dan fungsi Lembaga Hakim Wasmat sebagai Lembaga Pengawasan yang independen berarti harus merombak dan mengubah Undang-Undang Pemasyarakatan.

Pelaksanaan pengawasan melekat sebagai alatutama untuk memberikanjaminan kualitas (quality assurance) penyelenggaraan pemerintahan dilakukan secara berjenjang di setiap UPT Lembaga Pemasyarakatan, mulai dari Kepala, Kabag/kasubag TU, Kepala Bidang sampai ke Kepala seksi/kepala sub seksi dan pegawai/staff harus dilakukan sesuai aturan yang ada. Dalam pengertian bahwa kewajiban pimpinan organisasi dalam melakukan evaluasi terhadap kinerja bawahannya dilakukan secara terus menerus dimana hasil penilaian ini dituangkan dalam Daftar Capaian Kinerja atau daftar penilaian pelaksanaan pekerjaan.

Permasalahan lain adalah seberapa jauh efektifitas pengawasan melekat atau pengawasan atasan langsung terhadap kegiatan yang dilaksanakan oleh unit kerja yang berada di bawahnya mengingat masih adanya kecenderungan semangat untuk melindungi korps yang masih cukup tinggi. untuk lebih memastikan berjalannya roda organisasi secara lebih efektif dan efisien maka pihak internal Direktorat Jenderal Pemasyarakatan perlu menyusun prosedur tetap atau protap pengawasan yang juga mengatur tentang kode etik perilaku bagi semua petugaspemasyarakatan termasuk mekanisme pemberian reward and punishment. (Cetak Biru Lembaga Pemasyarakatan)

\section{b. Pengawasan Ekternal}

Secara umum dapat dikatakan bahwa pengawasan eksternal memiliki peran yang begitu penting dalam melakukan fungsi kontrol terhadap kinerja pemerintah. Secara sederhana pengawasan eksternal merupakan bentuk pengawasan yang dilakukan oleh pihak yang memiliki garis koordinasi secara langsung atau tidak langsung dalam organisasi Kementerian Hukum dan HAM sebagai induk dari organisasi pemasyarakatan. Melihat bentuk dan konsep mekanisme kontrol yang ada dalam sistem hukum dan politik, paling tidak terdapat 2 (dua) bentuk pengawasan eksternal terhadap kinerja organisasi pemasyarakatan, yakni pengawasan oleh masyarakat, dan pengawasan oleh hakim pengawas dan pengamat (Hakim Wasmat).

Pengawasan yang dilakukan oleh Hakim Wasmat sangat relevan dengan salah satu asas yang terkandung dalam hukum acara pidana, yaitu asas bahwa pengadilan berkewajiban 
mengendalikan pelaksanaan keputusannya. Peran seorang Hakim Wasmat yang cukup signifikan sebagaimana tercantum dalam KUHAP dan SEMA-RI, memungkinkan seorang Hakim melakukan pengawasan yang lebih spesifik pada pola perlakukan LAPAS kepada seorang WBP khususnya dalam pemberian remisi.

Bagi Hakim Wasmat, dalam melaksanakan tugasnya selain KUHAP dan Pedoman Pelaksanaan KUHAP sebagai dasar hukumnya, dilengkapi pula dengan:

1) Surat Edaran Mahkamah Agung Republik Indonesia (SEMA-RI) Nomor 3 Tahun 1984 Tentang Pelaksanaan Tugas Hakim Pengawas dan Pengamat ( Hakim Wasmat),

2) Surat Edaran Mahkamah Agung Republik Indonesia (SEMARI) Nomor 7 Tahun 1985 Tentang Petunjuk Pelaksanaan Tugas Hakim Pengawas Dan Pengamat.

Hakim Wasmat mempunyai tugas khusus selama 2 (dua) tahun untuk membantu Ketua Pengadilan Negeri dan tugas itu dilakukan dengan tujuan untuk memperoleh kepastian bahwa putusan pengadilan telah dilaksanakan sebagaimana mestinya danjuga digunakan untuk bahan penelitian demi ketetapan yang bermanfaat bagi pengaruh pemidanaan dan timbal balik dengan melihat tingkah laku narapidana.

Dalam menjalankan pengawasan dan pengamatan putusan pengadilan, hakim Wasmat lebih bersifat administratif dan pasif, yaitu menunggu laporan dari Jaksa yang berkaitan dengan pelaksanaan putusan pengadilan. Tugas pengawasan dan pengamatan dilaksanakan oleh Hakim Wasmat setelah Ketua Pengadilan menjatuhkan putusan pengadilan yang telah memperoleh kekuatan hukum tetap. Objek dari pengawasan dan pengamatan yang dilakukan oleh Hakim Wasmat adalah pelaksana putusan dan narapidana. Ketentuan ini disebutkan dalam Pasal 54 ayat (1) Undang-Undang Nomor 48 Tahun 2009 Tentang Kekuasaan Kehakiman.

Dalam SEMA-RI Nomor 7 Tahun 1985 Tentang Petunjuk Pelaksanaan Tugas
Hakim Wasmat, menyebutkan pula bahwa Hakim Wasmat harus datang ke Lembaga Permasyarakatan untuk mengadakan checking on the spot paling sedikit 3 (tiga) bulan sekali untuk memeriksa kebenaran berita acara pelaksanaan putusan pengadilan. Hakim Pengawas dan Pengamat ini sangat dibutuhkan dan penentuannya dilakukan oleh Ketua Pengadilan Negeri, minimal 1 (satu) orang Hakim Pengawas dan Pengamat di sebuah Pengadilan Negeri, selebihnya tergantung pada volume dari putusan pengadilan yang sudah mempunyai kekuatan hukum tetap.

Berdasarkan aturan hukum, sebenarnya Hakim Wasmat mempunyai peran yang sangat penting terutama sebagai fungsi kontrol, tetapi menurut Ketua LAPAS Kelas 1 Makassar, Hakim Wasmat menjalankan tugasnya hanya satu kali dalam setahun yaitu pada saat pemberian remisi setiap tanggal 17an (Wawancara dengan Kepala Seksi Pembinaan Narapidana dan anak didik Lembaga Pemasyarakatan Kelas 1 Makasaar, pada tanggal 26 April 2016), hal yang sama juga kami temukan di LAPAS Tanjung Kusta Medan, pengawasan yang seharusnya dilakukan oleh Hakim Wasmat tidak berjalan sebagaimana mestinya, karena Hakim Wasmat tidak pro aktif, Sehingga wajar apabila menurut petugas pemasyarakatan, kedatangan atau kunjungan Hakim Wasmat tidak menjadi hambatan bagi petugas dalam pembinaan narapidana di Lapas, artinya petugas pun di sini sudah tidak berharap banyak dengan keberadaan Hakim Wasmat tersebut.

Meskipun pengaturan tugas Hakim Wasmat sudah diatur dalam peraturan perundang-undangan yang telah ada, akan tetapi dalam pelaksanaannya masih mengalami beberapa hambatan. Menurut I Dewa Made Suartha dan I Gede Artha ( I Dewa Made Suartha dan I Gede Artha, Jurnal Magister Hukum Udayana Vol. 6 No. 2/2014 (275-290), hlm 287-288), terdapat berbagai faktor da kendala hakim wasmat dalam melaksanakan tugas sebagai pengawas dan pengamat yang meliputi: 


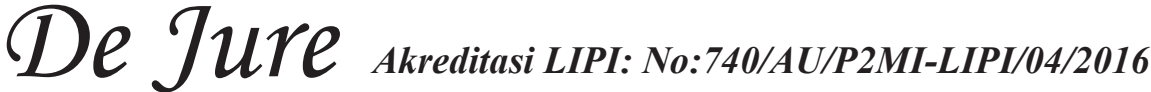

1) Jumlah hakim pengawas dan pengamat Pengadilan Negeri masih kurang cukup memadai;

2) Tidak ada dana khusus (operasional) untuk pelaksanaan tugas dan wewenang hakim pengawas dan pengamat Pengadilan Negeri;

3) Pengawasan hanya bersifat koordinasi antar pejabat terkait;

4) Hakimwasmathanya dapatmenghimbau untuk memberikan masukan kepada kepala/petugas pembinaan narapidana;

5) Tidak ada sanksi yang tegas, untuk hakim wasmat dan pejabat terkait yang tidak melaksanakan tugas dan wewenang sesuai dengan ketentuan peraturan perundang-undangan yang berlaku;

6) Untuk pengamatan narapidana yang telah menjalani pidananya di masyarakat tidak dapat dilaksanakan, karena sulit mencari datanya.

Sementara menurut SoerjonoSoekanto, ketentuan KUHAP tersebut tidak berjalan karena terdapat beberapa hal yang di identifikasikan sebagai faktor penyebab yaitu: (Soerjono Soekanto 1983),

1) Hakim yang ada di tiap-tiap pengadilan sering kali sudah disibukkan dengan tugas-tugas rutin peradilan, sehingga tugas sebagai Hakim Wasmat terabaikan,

2) Kurangnya personil Hakim yang ada pada pengadilan, sehingga tugas sebagai Hakim wasmat tidak dapat dijalankan,

3) Kurangnya koordinasi antar berbagai aparat penegak hukum.

Dalam hal ini tiap-tiap institusi penegak hukum sering kali masih mementingkan terlaksananya tugas masingmasing tanpa memikirkan kebutuhan institusi penegak hukum yang lain berkaitan dengan proses peradilan pidana.

Berdasarkan seluruh penjelasan di atas, dapat ditarik kesimpulan sementara bahwa fungsi pengawasan hak-hak narapidana apabila merujuk kepada KUHAP dan SEMARI Nomor 7 Tahun 1985 merupakan tanggung jawab Lembaga Hakim Wasmat. Sedangkan apabila merujuk kepada Undang-Undang Nomor 12 Tahun 1995 dan Keputusan Menteri Perundang-undangan RI Nomor M.02. PR.08.03 Tahun 1999, maka yang mempunyai fungsi pengawasan adalah BPP dan TPP di samping adanya fungsi pengawasan melekat dan pengawasan fungsional dalam intern Pemasyarakatan. Hakim Wasmat sama sekali tidak diadopsi menjadi suatu lembaga pengawasan yang mandiri oleh UndangUndang Pemasyarakatan.

Tidak dicantumkannya Hakim Wasmat pada Undang-Undang Nomor 12 Tahun 1995, kemungkinan karena lembaga yang dipelopori oleh Prof. Oemar Seno Adji (Alm) ini, dinilai telah gagal melaksanakan peran dan fungsinya selama ini, penilaian tersebut minimal menurut pembentuk dan pembuat Undang-Undang Nomor 12 tahun 1995 yang telah "memandulkan" Hakim Wasmat.

Dengan melihat kenyataan tersebut di atas, yang mana dalam praktiknya tidak membuahkan hasil apa-apa dan telah berubah menjadi lembaga pengawasan yang "banci", maka perlu dicari alternatif pemikiran lain di luar kerangka berfikir ketiga badan tersebut, sehingga lahirlah Lembaga Pengawasan di luar lembaga pengawasan yang telah ada, misalnya pembentukan lembaga khusus yang melakukan pengawasan baik terhadap pemberian remisi maupun terhadap hakhak narapidana lainnya, sehingga tujuan pemberian remisi seperti yang diamanatkan oleh Undang- Undang Nomor 12 Tahun 1995 dapat tercapai. Artinya menempatkan pemberian remisi betul-betul sebagai hak narapidana yang diberikan karena narapidana dan anak pidana yang bersangkutan telah menjalankan kewajibannya, bukan lagi sebagai hadiah dari Pemerintah, apalagi diberikan karena dibalut kepentingankepentingan.

Sementara, pengawasan oleh masyarakat secara implementatif belum bisa optimal berjalan, karena sampai saat ini belum ada mekanisme teknik prosedur yang pasti dan secara kontinyu bisa mengakomodasi pengawasan dari masyarakat. Hal ini penting mengingat ada dua persoalan mendasar yang menjadi kelemahan dalam pengawasan masyarakat, 
pertama pengawasan masyarakat sering bersifat kasuistis dan parsial, dan cenderung lebih banyak mengarah ke anggaran. Kedua, belum ada alur dan mekanisme yang tepat, tidak ada panduan yang menjadi pegangan sehingga sulit untuk mendapatkan data dan informasi tentang kondisi faktual dalam UPT Pemasyarakatan. Padahal keberhasilan pemasyarakatan ditentukan oleh daya dukung yang optimal dan partisipasi masyarakat yang dicirikan dengan adanya social control dan social support.

Dengan demikian, kehadiran instrumen atau perangkat yang mengatur tentang bagaimana keterlibatan masyarakat seperti media, lembaga non pemerintahan (LSM) dan perorangan dalam melakukan kontrol pengawasan pada tiap UPT Pemasyarakatan khususnya tentang pemberian remisi sangat mendesak untuk diwujudkan, sehingga proses pembinaan dan pelayanan pemberian remisi pada tiap-tiap UPT Permasyarakatan dapat berjalan secara optimal.

5. Aspek Positif dan Negatif Pemberian Remisi Kepada Narapidana Korupsi

Kebijakan pemberian remisi oleh pemerintah, di satu sisi harus diakui telah berdampak positif terhadap perkembangan pembinaan di LAPAS terutama untuk mengurangi over kapasitas, tetapi di sisi lain menimbulkan persoalan baru yaitu terjadi ketidakjelasan kriteria pemberian remisi, terjadi penyimpangan-penyimpangan dalam pelaksanaan pemberian remisi kepada Narapidana dan anak pidana di LAPAS. Kriteria pemberian remisi yang disyaratkan oleh Pasal 34 Peraturan Pemerintah Nomor 99 Tahun 2012 dan penjelasannya menyatakan bahwa, yang dimaksud dengan "berkelakuan baik" adalah tidak sedang menjalani hukuman disiplin dalam kurun waktu 6 (enam) bulan terakhir, terhitung sebelum tanggal pemberian Remisi; dan telah mengikuti program pembinaan yang diselenggarakan oleh LAPAS dengan predikat baik", dalam pelaksanaannya menjadi tidak jelas dan sangat tergantung penilaian serta kepentingan petugas dan LAPAS.

Pemberian remisi dimaksudkan juga untuk mengurangi dampak negatif dari sub-kultur tempat pelaksanaan pidana, disparitas pidana dan akibat pidana perampasan kemerdekaan(Menteri Hukum dan HAM, Sambutan Menteri Hukum dan Ham RI Pada upacara Pemberian Remisi
Kepada WBP Pada Upacara Memperingati Hari Ulang Tahun Proklamsi Kemerdekaan RI Ke63, Jakarta, 17 Agustus 2008). Secara psikologis pemberian remisi mempunyai pengaruh dalam menekan tingkat frustasi sehingga dapat mereduksi atau meminimalisasi gangguan keamanan dan ketertiban di LAPAS, RUTAN dan cabang RUTAN, berupa pelarian, perkelahian dan kerusuhan lainnya ((Menteri Hukum dan HAM, Sambutan Menteri Hukum dan Ham RI Pada upacara Pemberian Remisi Kepada WBP Pada Upacara Memperingati Hari Ulang Tahun Proklamsi Kemerdekaan RI Ke63, Jakarta, 17 Agustus 2008).).

Berdasarkan data lapangan yang berhasil dikumpulkan, pemberian remisi kepada narapidana tindak pidana korupsi menimbulkan pro dan kontra, baik di kalangan penegak hukum, aparatur pemasyarakatan, pemerhati pemasyarakatan, sampai pada narapidana itu sendiri. Untuk itu, analisis perlu diarahkan pada beberapa aspek positif dan negatif pemberian remisi tersebut. Dalam konteks tersebut, pertimbangan terhadap kedua aspek tersebut menjadi perlu untuk dianalisis mengingat pemberian remisi hakekatnya merupakan sebuah open legal policy. Adapun dalam analisis ini, aspek positif dan negatif akan ditinjau baik secara hukum maupun dari norma dan nilai hak asasi manusia.

\section{a. Aspek Positif Pemberian Remisi}

Data lapangan menunjukkan bahwa remisi pada prinsipnya: Pertama, dapat berkontribusi terhadap kelancaran proses pembinaan narapidana selama pembinaan di dalam LAPAS. Dalam hal ini, frasa 'berkelakuan baik' merupakan elemen dalam remisi yang berjalan seiring dengan program dan kegiatan pembinaan narapidana di dalam LAPAS. Mengingat fungsi reintegrasi sosial yang diemban dalam sistem pemasyarakatan, maka remisi sebagai reward dianggap merupakan capaian keberhasilan pembinaan dalam sistem tersebut.

Kedua, mengingat remisi adalah pengurangan masa hukuman maka pemberiannya dapat mengurangi tingkat over kapasitas yang terjadi di hampir seluruh LAPAS di Indonesia. Lebih jauh, melalui pemberian remisi diharapkan beban anggaran pemerintah akan berkurang. Terhadap argumentasi demikian, data hunian di LAPAS/ 


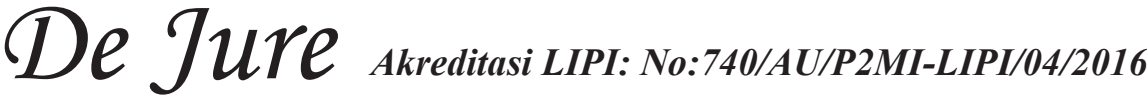

RUTAN seluruh Indonesia menunjukkan bahwa jenis tindak pidana yang memenuhi di seluruh UPT ialah yang terkait dengan narkotika dan obat terlarang. Oleh sebab itu, pemberian remisi kepada narapidana korupsi tidak serta-merta dapat dianggap sebagai faktor yang siginifikan dalam mengurangi tingkat over-kapasitas di LAPAS.

Ketiga, remisi sebagai bentuk upaya pemerintahdalammemperlakukannarapidana secara manusiawi. Dasar argumentasi ini ialah fakta bahwa banyak narapidana kasuskasus korupsi yang memiliki keluarga, sehingga remisi dianggap sebagai harapan bagi mereka untuk bisa kembali ke keluarga masing-masing, serta dapat berkarya kembali di masyarakat.

Keempat, remisi merupakan bagian dari hak yang wajib dilindungi oleh negara. Berangkat dari pemahaman tersebut, ketika hak terhadap remisi diperketat maka dikuatirkan akan meningkatkan sub-kultur negatif yang ada di Lapas. Melalui pemberian remisi, diharapkan potensi terjadinya gangguan keamanan dan ketertiban di LAPAS akan berkurang, mengingat pembatasan hak tersebut dapat memengaruhi suasana psikologis narapidana selama menjalani pembinaan di LAPAS. Pada sisi yang lain, remisi menjadi salah satu alat yang digunakan oleh otoritas LAPAS untuk melakukan kontrol terhadap prilaku narapidana. Dengan demikian, hak untuk remisi adalah satu instrumen yang mampu menjaga stabilitas penjara.

\section{b. Aspek Negatif Pemberian Remisi}

Pada sisi yang lain, pemberian remisi kepada narapidana tindak pidana korupsi juga menimbulkan berbagai aspek negatif meliputi: pertama, bertentangan dengan semangat nasional untuk memberantas korupsi. Argumentasi tersebut didasarkan pada sifat kejahatan tindak pidana korupsi yang luar biasa, sehingga kalaupun kebijakan tersebut tetap ada, maka pertimbangan perlu diarahkan pada efektivitas efek jera dari konsep pemidanaan secara nasional.

Kedua, terkait dengan kasus korupsi, sesungguhnya banyak narapidana yang terzalimi dalam arti tidak memiliki niat untuk berbuat koruptif namun hanya sekedar menjalankan kewenangan yang ada padanya selaku aparatur negara tetapi oleh sistem hukum yang berliku harus dipidana dan dicap sebagai koruptor walaupun jelas-jelas tidak menikmati hasil yang dimaksud.

\section{KESIMPULAN}

Pola pemidanaan yang dianut Indonesia saat ini adalah gabungan antara teori absolut dan relatif, dengan demikian terdapat keseimbangan antara pembalasan untuk menimbulkan efek jera dan pembinaan agar narapidana dapat kembali ke masyarakat dan tidak mengulangi perbuatannya.

Prosedur dan pelaksanaan pemberian remisi untuk narapidana korupsi berdasarkan ketentuan PP No 99 tahun 2012, saat ini masih belum banyak diketahui narapidana korupsi. Keterangan Justice Collaborator.

Pengawasan internal dan eksternal dalam pemberian remisi narapidana korupsi belum berfungsi secara optimal, terutama pengawasan yang dilakukan oleh TPP, BPP dan Hakim Wasmat.Aspek positif pemberian remisi kepada narapidana korupsi adalah dapat mengurangi masa pemidanaan bagi yang bersangkutan Sedangkan bagi pemerintah dapat mengurangi persoalan overkapasitas dan merngurangi anggaran. Sedangkan sisi negatif pemberian remisi kepada narapidana korupsi adalah terdapat perasaan tidak adil dalam masyarakat karena menganggap korupsi itu adalah perbuatan jahat yang harus dibalas dan tidak perlu diberi ampun.

\section{SARAN}

Dengan adanya polemik mengenai keberadaan PP 99/2012 dimana ada pembedaan syarat pemberian remisi kepada narapidana tertentu termasuk narapidana korupsi maka disarankan agar peraturan tersebut ditinjau ulang terutama mengenai keterlibatan instansi terkait dalam menentukan narapidana korupsi untuk mendapatkan remisi (surat Justice Collaborator). Perlu sosialisasi mengenai hak hak narapidanan khusunya narapidanan korupsi menganai prosedur dan persyaratan untuk mendapatkan remisi. Dalam rangka mengoptimalkan kembali Lembaga Hakim Wasmat dalam KUHAP, maka perlu dilakukan perubahan terhadap Undang-Undang Nomor 12 Tahun 1995. Agar sistem pemasyarakatan benar 


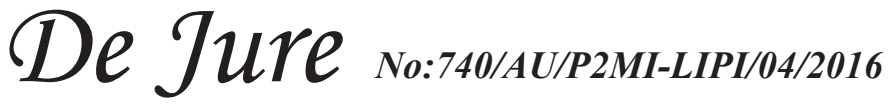

benar mengacu kepada teory pemidanaan yang dianut dalam sistem hukum pidana Indonesia, yaitu adanya keseimbangan antara penjeraan dengan pembinaan. 


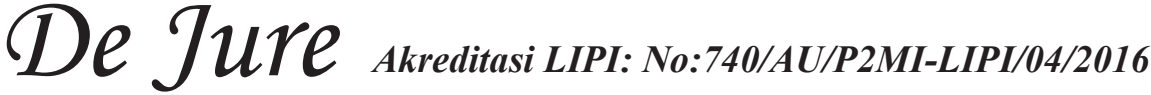

\section{DAFTAR KEPUSTAKAAN}

\section{A. Buku}

Andi hamzah, 2007, Terminologi Hukum Pidana, Sinar Grafika, Jakarta

Barda Nawawi Arief, Bunga Rampai Kebijakan Hukum Pidana, Bandung, PT. Citra Aditya Bakti, 2006

Bambang Poernomo, 1985 Pelaksanaan Pidana penjara dengan Sistem Pemasyarakatan, Yogyakarta, Liberty

C.I. Harsono, 1995, Sistem Baru Pembinaan Narapidana, Jakarta, Djambatan,

Dwidja Priyatno, 2009, Sistem Pelaksanaan Pidana Penjara di Indonesia, PT Refika Elwi Danil, 2011, Korupsi, Konsep, Tindak Pidana dan Pemberantasannya, Rajawali Pers, Jakarta, Aditama, Bandung

Muhammad Erwin, 2011, Filsafat Hukum Refleksi Kritis terhadap Hukum, Rajawali Pres, Jakarta

Mardjono, Reksodiputro, 2007, Pembaharuan Hukum Pidana. Pusat Pelayanan Keadilan dan Hukum Universitas Indonesia, Jakarta

Marlina, Hukum Penintesier 2011, PT. Refika aditama, Jakarta

Romli Atmasasmita, 2009, Perbandingan HukumPidana, Jakarta:Penerbit Fikahati

Soerjono Soekamto, Pengantar Penelitian Hukum, Cetakan Ketiga, Jakarta, UU Press 1996

Soerjono Soekanto, 1983, Faktor-Faktor Yang Mempengaruhi Penegakkan Hukum, Jakarta, Rajawali

Sudarto, 1990, Hukum Pidana I, Semarang: Yayasan Sudarto

Saldi Isra, dan Eddy O.C. Hiariej "Perspektif Hukum Pemberantasan Korupsidi Indonesia" dalam Wijayanto dan Ridwan Zachrie

Teguh Sulistia dan Aria Zurnetti, 2011, Hukum Pidana Horizon Baru Pasca Reformasi, Rajawali Pers, Jakarta

\section{B. Peraturan Perundang-undangan}

Republik Indonesia, Undang-Undang Nomor 12 Tahun 1995 tentang Pemasyarakatan, LN tahun 1995 Nomor. 77, TLN Nomor 3614.
Kitab Undang-Undang Hukum Pidana Undang-Undang Nomor 39 Tahun 1999 tentang Hak Asasi Manusia, LN tahun 1999 Nomor. 165, TLN Nomor 3886.

Undang-UndangNomor 48 tahun 2009 tentang Kekuasaan Kehakiman, LN tahun 2009 Nomor 57, TLN Nomor 5076.

, Undang-Undang Nomor 30 Tahun 2002 tentang Komisi Pemberantasan Tindak Pidana Korupsi

Undang-Undang No 31 Tahun 1999 tentang Pemberantasan Tindak Pidana Korupsi

- Peraturan Pemerintah Nomor 32 Tahun 1999 tentang Syarat dan Tata Cara Pelaksanaan Hak Warga Binaan Pemasyarakatan, LN tahun 1999 Nomor 69, TLN Nomor 3846.

Peraturan Pemerintah Nomor 31 Tahun 1999 tanggal 19 Mei 1999 tentang Pembinaan dan Pembimbingan WBP

Peraturan Pemerintah Nomor 28 Tahun 2006 tentang Perubahan Atas Peraturan Pemerintah Nomor 32 tahu 1999 tentang Syarat dan Tata Cara Pelaksanaan Hak Warga Binaan Pemasyarakatan, LN tahun 2006 Nomor 61, TLN Nomor 4632.

Keputusan Presiden Nomor 174 tahun 1999 tentang Remisi, LNtahun 1999 Nomor. 223, TLN Nomor. 3845

Keputusan Presiden No. 156 tahun 1950 tentang Remisi

Keputusan Menteri Hukum dan Perundang-undangan tentang Pembentukan Balai Pertimbangan Pemasyarakatan dan Tim Pengamat Pemasyarakatan.. Kepmen Nomor M.02.PR.08-03 tahun 1999.

Peraturan Kementerian Hukum dan HAM RI Nomor 29 Tahun 2015 tanggal 29 September 2015 Tentang Organisasi Dan Tata Kerja Kementerian Hukum dan HAM RI.

,Surat Edaran Menteri Hukum dan HAM Nomor PAS-HM.01.02-42 tanggal 31 Oktober 2011 tentang Moratorium Pemberian Hak Narapidana Tindak Pidana Korupsi dan Terorisme. 


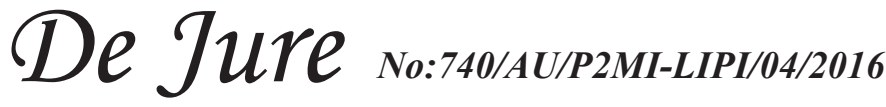

, Surat Edaran Menteri Hukum dan HAM Nomor M.HH-04.PK.01.05.06 Tahun 2013 tentang Petunjuk Pelaksanaan Pemberlakuan PP 99/ 2012

, SEMANo. 7 tahun 1985 tentang Petunjuk Pelaksanaan Tugas Hakim Pengawas dan Pengamat.

, SEMANo. 4 tahun 2011 tentang Perlakua Bagi Pelapor Tindak Pidana (Whistleblower) dan Saksi Pelaku yang Bekerjasama (Justice Collaborrator) di dalam Perkara Tindak Pidana Tertentu.

\section{Sumber lain}

\section{Internet}

Sambutan Menteri Hukum dan Ham RI Pada upacara Pemberian Remisi Kepada WBP Pada Upacara Memperingati Hari Ulang Tahun Proklamsi Kemerdekaan RI Ke63, Jakarta, 17 Agustus 2008

Cetak Biru Pembaharuan Pelaksanaan Sistem Pemasyarakatan Departemen Hukum dan Hak Asasi Manusia Dirjen Pemasyarakatan tahun 2008

http://sp.beritasatu.com/home/menkumhambuka-kemungkinan-revisi-pp-no-99-tahun2012-tentang -pemberian-remisi/91833, di akses pada tanggal 9 Februari 2016.

http://www.hukumonline.com/berita/baca/ 1t53f37cde7c605/icw--cabut-surat-edaranremisi-pro-koruptor, di akses pada tanggal 5 Februari 2016

asashukumpidana.blogspot.com/, diakses 21 Maret 2016 pukul 14.00 WIB

http://politik.kompasiana.com/2010/04/28/dramaanomali-prinsip-equality-before-the-law/, diakses 21 april 2016 pukul 09.00

http://www.hukumonline.com/berita/baca/ 1t53f37cde7c605/icw--cabut-surat-edaranremisi-pro-koruptor

http://sp.beritasatu.com/home/menkumhambuka-kemungkinan-revisi-pp-no-99-tahun2012-tentang-pemberian-remisi/91833, di akses pada tanggal 9 Februari 2016.

http://www.hukumonline.com/berita/baca/ 1t53f37cde7c605/icw--cabut-surat-edaranremisi-pro-koruptor, di akses pada tanggal 5 Februari 2016 


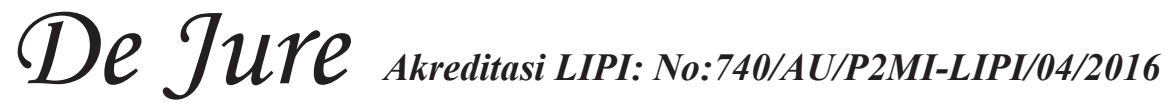

\section{BIODATA PENULIS}

Nama, Mosgan Situmorang, S.H., M.H., Tempat/Tanggal Lahir: Tapanuli 6 April 1961, Pekerjaan : Puslitbang Sistem Hukum Nasional, BPHN Kementerian.Hukum Dan HAM RI, Jabatan : Peneliti Utama, Pangkat/Golongan : Pembina Utama/IVe, NIP : 196104061989 031001, Pendidikan Terakhir: S2 Ilmu Hukum, Alamat: Jl. Cempedak VII/231 Jatimulya Bekasi, Telepon: (021) 820 2413, Riwayat Pendidikan 1973 Lulus SD Negeri Kebun Sayur Deli Serdang Sumut, 1976 Lulus SMP Negeri Sei Rampah Deli Serdang Sumut, 1980 Lulus SMA Negeri 29 Jakarta, 1987 Lulus S1 Fakultas Hukum Universitas Jayabaya Jakarta 2003, Lulus S2 STIH IBLAM Jakarta, Riwayat Pekerjaan: 1981 - 1988 Pegawai Perum Percetakan Uang RI, 1989 - 1993 Bidang Pertemuan Ilmiah, Pusat Pembinaan Sistem dan Pranata Hukum Nasional, BPHN Dep. Kehakiman, 1993 - 1995 Peneliti Pada Pusat Penelitian dan Pengembangan Sistem Hukum Nasional BPHN, Kementerian Hukum dan HAM, 2016 - sekarang, Peneliti Utama pada Pusat Penelitian Hukum Badan Litbang Keneterian Hukum dan HAM RI. 2006 - sekarang dosen pada Fakultas Hukum Universitas Atma Jaya Jakarta mata kuliah ADR dan Legislative Drafting, 2011 - sekarang dosen Pada STIH Litigasi Pengayoman, mata kuliah Bahasa Inggris Hukum Kursus / Penelitian : 1. Work at UNCITRAL on Reforming the 1958 New York Convention In Particular Regarding Refusal of Enforcement of Arbitral Awards, In the Light Recent Practice in Indonesia, Europe and America, a Research Program Conduct in Max-Planck Institute for International and Private Law, Hamburg Germany 3 March - 31 May 2003 (Bea Siswa dari Max-Planck Jerman \} . 2. "Cross-Border Insolvency-Comparative \& International Law Aspect", a research program conduct in UNIDROIT Rome Italy 1 April -31 May 2001 (Bea Siswa dari Pemerintah Korea Selatan dan UNIDROIT), 3. Insolvency and Commercial law in a Global Economy at the Faculty of Law, University of Melbourne Australia, a five weeks Course November 1998 - December 1998 ( Bea Siswa dari AUSAID Australia), 4. The Protection Against Indonesian Migrant Worker a Research Project held in Singapore and Malaysia, January 1996.( Kerja sama BPHN dan PT (persero) ASTEK), 5. The Protection Against Indonesian Migrant Worker a Research Project held in Hong Kong, November 1996. (kerja sama BPHN dan PT (persero) ASTEK), 6. Mediation Course held by Bond University Australia in Jakarta 1999 (kerja sama Departemen Kehakiman RI dan AUSAID), 7. Kursus Bahasa Inggeris AISI Jakarta Tahun 1979, 8. Kursus Bahasa Inggeris IEC Jakarta Tahun 1980, 9. Kursus Bahasa Inggeris LIA Jakarta Tahun 1986. 


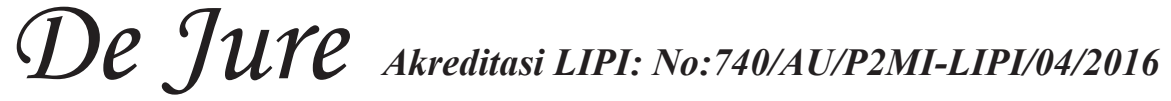

\section{PEDOMAN PENULISAN NASKAH JURNAL PENELITIAN HUKUM DE JURE}

1. Naskah yang dimuat dalam Jurnal Penelitian Hukum De Jure adalah tulisan yang belum pernah dipublikasikan dalam media massa.

2. Naskah yang dimuat dalam Jurnal Penelitian Hukum De Jure meliputi tulisan tentang hasil penelitian (penelitian empiris maupun penelitian normatif atau studi dokumenter), pemikiran dan informasi lain yang bersifat ilmiah.

3. Menggunakan bahasa Indonesia yang baku.

4. Sistimatika Penulisan :

A. Naskah artikel hasil penelitian empiris :

o Judul aktual

Menggambarkan isi naskah dan maksimal 14 kata ditulis dalam bahasa Indonesia dan Inggris

o Nama penulis

Tanpa gelar akademik, jabatan, kepangkatan, alamat lembaga/instansi dan e-mail

o Abstrak

Berisi Latar Belakang, Rumusan Masalah, Tujuan, Kegunaan, Metode, Isi

Pembahasan, Analisis, Kesimpulan dan Saran Temuan ditulis dalam satu spasi;

150 kata (10-20 baris/ satu (1) paragraf) diketik menggunakan huruf Times New

Roman; font 11 italic; ditulis dalam bahasa Indonesia dan bahasa Inggris.

o Kata Kunci

Mengandung yang di indekskan ditulis dalam bahasa Indonesia dan Inggris

dengan minimal 3 kata maksimal 5 kata

- PENDAHULUAN

Berisi latar belakang masalah dan rumusan masalah, tujuan, kegunaan, kerangka Teori/Konsep, Metode (metode penelitian yang digunakan, di antaranya meliputi jenis penelitian, lokasi penelitian, sumber data, teknik pengumpulan data, pengolahan data dan analisis data.)

- PEMBAHASAN

Berisi, pembahasan terhadap masalah yang diteliti

- Analisis

Berisi analisis dari semua pokok pembahasan

- PENUTUP

Kesimpulan dan saran

Kesimpulan dan saran ditulis dalam bentuk uraian bukan dalam bentuk'angka

- DAFTAR KEPUSTAKAAN

Daftar Pustaka : ditulis berdasarkan abjad, dengan urutan : Nama pengarang. Judul buku. Kota penerbit: nama penerbit, tahun penerbitan.

Contoh ....Hamzah. Andi, Bantuan Hukum suatu Tinjauan Yuridis. Ghalia

Indonesia, Jakarta, 1983. 


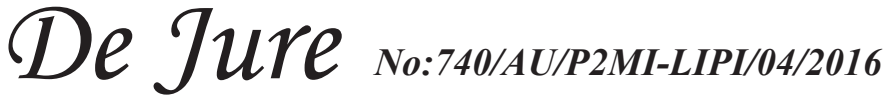

B. Naskah artikel ulasan Hasil penelitian normatif atau studi dokumenter), pemikiran dan informasi lain yang bersifat ilmiah.

o Judul aktual

Menggambarkan isi naskah dan maksimal 14 kata ditulis dalam bahasa

Indonesia dan Inggris

o Nama penulis

Tanpa gelar akademik, jabatan, kepangkatan, alamat lembaga/instansi dan e-mail

o Abstrak

Berisi Latar Belakang, Rumusan Masalah, Tujuan, Kegunaan, Metode, Isi

Pembahasan, Analisis, Kesimpulan dan Saran Temuan ditulis dalam satu spasi;

150 kata (10-30 baris/ satu (1) paragraf) diketik menggunakan huruf Times

New Roman; font 11 italic; ditulis dalam bahasa Indonesia dan bahasa Inggris

o Kata Kunci

Mengandung yang di indekskan ditulis dalam bahasa Indonesia dan Inggris

minimal 3 kata maksimal 5 kata

- PENDAHULUAN

Latar belakang masalah dan rumusan masalah

- PEMBAHASAN

Berisi, pembahasan terhadap masalah yang dikaji

- ANALISIS

Berisi analisis dari semua pokok pembahasan

- PENUTUP

Kesimpulan Dan Saran

Kesimpulan dan saran ditulis dalam bentuk uraian bukan dalam bentuk angka

- DAFTAR KEPUSTAKAAN

Daftar Pustaka : ditulis berdasarkan abjad, dengan urutan : Nama pengarang. Judul buku. Kota penerbit : nama penerbit, tahun penerbitan.

Contoh ....Hamzah. Andi, Bantuan Hukum suatu Tinjauan Yuridis. Ghalia

Indonesia, Jakarta, 1983.

5. Naskah dilengkapi dengan indeks.

6. Naskah diketik rapi 1,5 spasi di atas kertas A4; menggunakan huruf Times New Roman; Font 11; antara 20-30 halaman; diprint out dan disertai soft copy CD.

7. Penulisan kutipan sumber rujukan dengan sistem bodynote, yaitu menulisk ${ }^{\wedge} \mathrm{n}$ nama pengarang (tanpa gelar akademik); tahun penerbitan dan no halaman, yang ditulis dalam kurung; diletakan dibelakang kutipan. Contoh : .(Hamzah, 2007: 15)

8. Isi tulisan di luar tanggungjawab redaksi. Dan redaksi berhak mengedit redaksional tanpa merubah arti.

9. Naskah yang belum memenuhi syarat akan dikonfirmasikan atau dikembalikan untuk diperbaiki.

10. Keterangan lengkap dapat menghubungi redaksi Jurnal Peneltian Hukum De Jure melalui Email: jurnaldejure@yahoo.com 
